\title{
STAT1 modulates tissue wasting or overgrowth downstream from PDGFR $\beta$
}

\author{
Chaoyong He, ${ }^{1,2}$ Shayna C. Medley, ${ }^{1,3}$ Jang Kim, ${ }^{1}$ Chengyi Sun, ${ }^{1,3}$ Hae Ryong Kwon, ${ }^{1}$ \\ Hiromi Sakashita, ${ }^{1}$ Yair Pincu, ${ }^{1}$ Longbiao Yao, ${ }^{1}$ Danielle Eppard, ${ }^{1}$ Bojie Dai, ${ }^{3}$ William L. Berry, ${ }^{3}$ \\ Timothy M. Griffin, ${ }^{4}$ and Lorin E. Olson ${ }^{1,3}$ \\ ${ }^{1}$ Cardiovascular Biology Research Program, Oklahoma Medical Research Foundation, Oklahoma City, Oklahoma 73104, USA; \\ ${ }^{2}$ State Key Laboratory of Natural Medicines, Department of Pharmacology, China Pharmaceutical University, Nanjing 210009 , \\ China; ${ }^{3}$ Department of Cell Biology, University of Oklahoma Health Sciences Center, Oklahoma City, Oklahoma 73104, USA; \\ ${ }^{4}$ Aging and Metabolism Research Program, Oklahoma Medical Research Foundation, Oklahoma City, Oklahoma 73104, USA
}

\begin{abstract}
Platelet-derived growth factor (PDGF) acts through two conserved receptor tyrosine kinases: PDGFR $\alpha$ and PDGFR $\beta$. Gain-of-function mutations in human PDGFRB have been linked recently to genetic diseases characterized by connective tissue wasting (Penttinen syndrome) or overgrowth (Kosaki overgrowth syndrome), but it is unclear whether PDGFRB mutations alone are responsible. Mice with constitutive PDGFR $\beta$ signaling caused by a kinase domain mutation $(\mathrm{D} 849 \mathrm{~V})$ develop lethal autoinflammation. Here we used a genetic approach to investigate the mechanism of autoinflammation in $P d g f r b^{+/ D 849 V}$ mice and test the hypothesis that signal transducer and activator of transcription 1 (STAT1) mediates this phenotype. We show that Pdgfrb ${ }^{+/ D 849 V}$ mice with Stat1 knockout $\left(\right.$ Stat $^{-/-}$Pdgfrb $\left.{ }^{+/ D 849 V}\right)$ are rescued from autoinflammation and have improved life span compared with Stat ${ }^{+/-}$ Pdgfrb ${ }^{+/ D 849 V}$ mice. Furthermore, PDGFR $\beta$-STAT1 signaling suppresses PDGFR $\beta$ itself. Thus, Stat $1^{-/-}$

$P d g f r b^{+/ D 849 V}$ fibroblasts exhibit increased PDGFR $\beta$ signaling, and mice develop progressive overgrowth, a distinct phenotype from the wasting seen in Stat1 ${ }^{+/-}$Pdgfrb ${ }^{+/ D 849 V}$ mice. Deletion of interferon receptors (Ifnar1 or Ifngr1) does not rescue wasting in $P d g f r b^{+/ D 849 V}$ mice, indicating that interferons are not required for autoinflammation. These results provide functional evidence that elevated PDGFR $\beta$ signaling causes tissue wasting or overgrowth reminiscent of human genetic syndromes and that the STAT1 pathway is a crucial modulator of this phenotypic spectrum.
\end{abstract}

[Keywords: STAT; interferon; inflammation; skeleton; dermis; adipose tissue; fibrosis]

Supplemental material is available for this article.

Received April 11, 2017; revised version accepted August 21, 2017.

Platelet-derived growth factors (PDGFs) are essential for embryo development, and increased PDGF signaling is known to drive cancer, cardiovascular disease, and fibrosis (Andrae et al. 2008). The two PDGF receptors, PDGFRa and PDGFR $\beta$, are highly similar receptor tyrosine kinases (RTKs) expressed by a variety of mesenchymal-derived cell types, including fibroblasts, pericytes, vascular smooth muscle cells (VSMCs), and mesenchymal stem/progenitor cells. Ligand binding to PDGFRs leads to receptor dimerization and autophosphorylation on multiple tyrosine residues in the intracellular domain. Specific phosphotyrosines serve as docking sites for adaptor proteins that activate downstream signaling pathways, including phosphatidylinositol 3-kinase (PI3K), phospholipase $\mathrm{C}_{\gamma}$ (PLC $\gamma)$, mitogen-activated protein kinases (MAPKs), and signal transducer and activator of transcription (STAT) (Heldin and Westermark 1999; Tallquist and Kazlauskas

Corresponding author: lorin-olson@omrf.org Article published online ahead of print. Article and publication date are online at http://www.genesdev.org/cgi/doi/10.1101/gad.300384.117.
2004). By mutating individual amino acids that bind specific signaling adaptors, it has been shown that PDGFR $\alpha$ signals mainly through PI3K during development (Klinghoffer et al. 2002), while PDGFR $\beta$ uses additive signaling through multiple intracellular pathways (Tallquist et al. 2003). Nevertheless, it has yet to be fully elucidated how these signaling pathways mediate PDGFR function, and the role of STAT proteins has never been adequately addressed.

To analyze potential roles of elevated PDGFR $\beta$ signaling in disease, we previously established Pdgfrb knockin mice in which a PDGFR $\beta$ cDNA bearing a constitutively activating D849V point mutation could be expressed from the endogenous Pdgfrb locus in a Cre/lox-inducible fashion. When Sox2-Cre was used to induce a germline

(C) 2017 He et al. This article is distributed exclusively by Cold Spring Harbor Laboratory Press for the first six months after the full-issue publication date (see http://genesdev.cshlp.org/site/misc/terms.xhtml). After six months, it is available under a Creative Commons License (Attribution-NonCommercial 4.0 International), as described at http://creativecommons.org/licenses/by-nc/4.0/. 
D849V mutation in epiblast-derived cells, Sox2-Cre; $P d g f r b^{+/ D 849 V}$ mutants died by 2 wk of age with three principal phenotypes: VSMC hyperplasia and dilation of the aorta, autoinflammation with infiltration of leukocytes into the tissues, and lipoatrophy /Olson and Soriano 2011). While VSMC defects were not entirely surprising given the known biology of PDGFR $\beta$, the causes of autoinflammation, tissue atrophy, and juvenile lethality remain mysterious.

Recently, PDGFR $\beta$-activating mutations have been linked to rare human syndromes affecting the skin, fat, and bones. Kosaki overgrowth syndrome (Online Mendelian Inheritance in Man [OMIM] 616592) is characterized by increased linear growth during adolescence and has been linked to P584R or W566R mutations in the juxtamembrane domain of PDGFR $\beta$ (Takenouchi et al. 2015; Minatogawa et al. 2017). Penttinen syndrome (OMIM 601812 ) is a clinically distinct condition characterized by a prematurely aged appearance with dermal wasting, lipoatrophy, and bone loss, which has been linked to V665A mutations in the kinase domain (Johnston et al. 2015). Other activating mutations have been identified in infantile myofibromatosis, a soft tissue tumor of early childhood (Cheung et al. 2013; Martignetti et al. 2013). Several of these PDGFRB mutations have been shown to generate constitutive PDGFR $\beta$ signaling (Johnston et al. 2015; Arts et al. 2016), supporting the idea that disease arises by gain-of-function mechanisms. However, there is still no clear evidence that PDGFR $\beta$ activation alone can cause connective tissue phenotypes. In many cases of cancer and genetic diseases, additional mutations are required or have the ability to modify disease phenotypes. Moreover, there is currently no model of pathogenesis to explain the spectrum of phenotypes associated with activating mutation in PDGFRB. This is in contrast to genetic evidence from mice and humans that loss-of-function mutations in PDGFRB or PDGFB cause idiopathic basal ganglion calcification type 4 (Keller et al. 2013; Nicolas et al. 2013).

The initial goal of this study is to explain the autoinflammation and causes of death in Sox2-Cre Pdgfrb ${ }^{+/ D 849 V} \mathrm{mu}-$ tant mice. Because microarray analysis demonstrated upregulation of interferon (IFN)-stimulated genes (ISGs) in the tissue of Sox2-Cre Pdgfrb ${ }^{+/ D 849 V}$ mutants (Olson and Soriano 2011), we hypothesized that gain-of-function PDGFR $\beta$ signaling might cause autoinflammation via STAT1. Wild-type PDGFR $\beta$ is known to phosphorylate and activate STAT1 (Silvennoinen et al. 1993), a principal signal-transducing transcription factor in the IFN pathway (Levy and Darnell 2002), but the biological significance of PDGFR $\beta-S T A T 1$ signaling is still unknown. Our hypothesis is supported by recent findings that tissue-specific Stat1 knockout in PDGFR $\beta^{\mathrm{D} 849 \mathrm{~V}}$-expressing VSMCs significantly reduced vascular inflammation and atherosclerosis in ApoE-deficient mice (He et al. 2015). Therefore, we generated mice with germline Stat1 and/or Pdgfrb mutations in epiblast-derived cells using Sox2-Cre. The use of Sox2-Cre approximates a sporadic Pdgfrb mutation in the early embryo that is proposed to occur in the human syndromes. These experiments revealed that
PDGFR $\beta$-STAT1 signaling is indeed responsible for autoinflammation, lipoatrophy, and juvenile lethality. We also identified skeletal degeneration as a new phenotype driven by PDGFR $\beta$-STAT1 signaling. In cultured fibroblasts, STAT1 mediates negative feedback to suppress PDGFR $\beta$ expression and function. Correspondingly, in the absence of STAT1, PDGFR $\beta^{\mathrm{D} 849 \mathrm{~V}}$-expressing mice develop novel phenotypes, including fibrosis of the skin and fat and skeletal overgrowth. Together, these findings provide the first functional evidence that PDGFR $\beta$ mutations cause skin and skeleton phenotypes. This provides strong evidence that PDGFRB mutations identified in Penttinen syndrome and Kosaki overgrowth syndrome are causal. In addition, these results suggest that the STAT1 pathway is a crucial disease modifier in PDGFRB-related syndromes involving connective tissue degeneration or overgrowth.

\section{Results}

Activated STAT1 becomes phosphorylated on Tyr701 (Y701), which allows STAT1 dimers to enter the nucleus and activate ISG expression. We initially examined the effects of different PDGFR $\beta$-activating mutations on STAT1 phosphorylation, since this has not been reported for the mutations linked to human disease. Therefore, we transfected NIH3T3 cells with expression vectors encoding GFP, murine wild-type PDGFR $\beta, \operatorname{PDGFR} \beta^{\mathrm{D} 849 \mathrm{~V}}$, PDGFR $\beta^{\text {P583R }}$ (corresponding to human P584R, Kosaki overgrowth syndrome), or PDGFR $\beta^{\mathrm{V} 664 \mathrm{~A}}$ (corresponding to human V665A, Penttinen syndrome). Under low-serum conditions, STAT1 was highly phosphorylated by all mutants, as compared with GFP or wild-type PDGFR $\beta$ (Fig. 1A). This suggests that constitutive PDGFR $\beta-S T A T 1$ signaling is a general feature of PDGFR $\beta$-activating mutations. Notably, overexpression of wild-type PDGFR $\beta$ resulted in considerable PDGFR $\beta$ autophosphorylation compared with control cells with GFP, but only the mutant receptors were able to phosphorylate STAT1 to a significant level.

We previously described PDGFR $\beta^{\mathrm{D} 849 \mathrm{~V}}$ knock-in mice (Olson and Soriano 2011). The D849V point mutation is located in the receptor kinase domain, where it destabilizes the autoinhibited conformation of the receptor and thereby increases kinase activity and downstream signaling. Importantly, this allele is Cre-dependent such that PDGFR $\beta^{\mathrm{D} 849 \mathrm{~V}}$ is expressed under the control of the endogenous Pdgfrb promoter following Cre/lox deletion of a transcriptional stop cassette (Fig. 1B). When Sox2-Cre is used to activate this allele in the epiblast, the resulting Sox2-Cre Pdgfrb ${ }^{+/ D 849 V}$ mice express PDGFR $\beta^{\mathrm{D} 849 \mathrm{~V}}$ in all PDGFR $\beta^{+}$cells. These mice fail to thrive and survive only 2 wk postnatal.

Stat 1 deletion rescues juvenile wasting in Sox2-Cre $\mathrm{Pdgfrb}^{+/ \mathrm{D} 849 \mathrm{~V}}$ mice

To determine whether the cause of death involves STAT1, we established a breeding strategy using Sox2-Cre for germline deletion of Stat1-floxed alleles and/or activation 


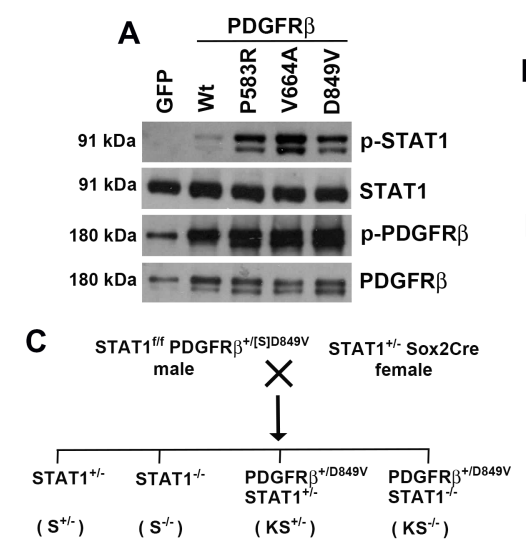

B

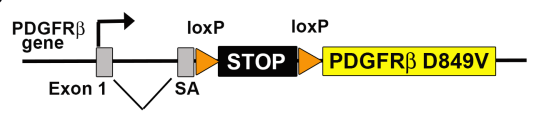

E

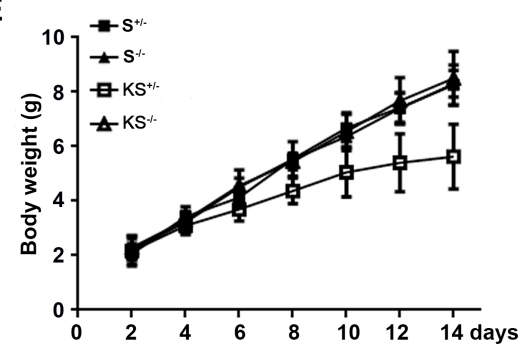

D

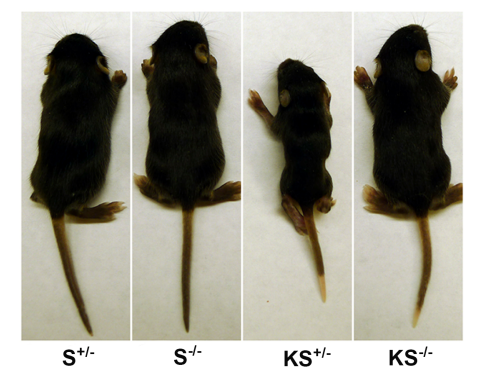

F

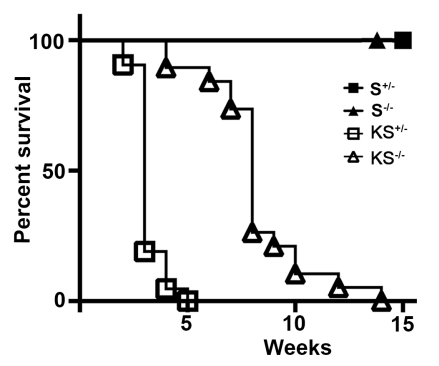

Figure 1. STAT1 is required for juvenile wasting in $P d g f r \beta^{+/ D 849 V}$ mice. (A) STAT1 Y701 phosphorylation in NIH3T3 cells transfected with GFP, wild-type PDGFR $\beta$, or three different constitutively active mutants. Cells were serum-starved in DMEM $+0.1 \%$ FBS. Transfection and blot were performed twice with the same result. $(B)$ Schematic of the D849V knock-in allele, which expresses a Cre-inducible PDGFR $\beta$ mutant cDNA under the control of the endogenous $P d g f r b$ promoter. (SA) Splice acceptor. (C) Diagram of the breeding strategy for generating four genotypes of offspring with combinations of Stat1 knockout and PDGFR $\beta^{\text {D849V }}$ activation in the germline. $(D)$ Outward appearance of littermate pups at postnatal day $10(\mathrm{P} 10)$. (E) Body weight of pups measured from P2 to P14. $n=5$ pups per genotype. Data represent mean \pm SD. $(F)$ Kaplan-Meier survival curve for cohorts of mice. Median survival of $\mathrm{KS}^{+/-}$and $\mathrm{KS}^{-/-}$was 3 and $8 \mathrm{wk} . \mathrm{KS}^{+/-}$and $\mathrm{KS}^{-/-}$curves are significantly different, $P<0.0001$ by log-rank test. $n=18 \mathrm{~S}^{+/-}$; $n=23 \mathrm{~S}^{-/-} ; n=21 \mathrm{KS}^{+/-} ; n=19 \mathrm{KS}^{-/-}$. of PDGFR $\beta^{\mathrm{D} 849 \mathrm{~V}}$. For simplicity, mice with PDGFR $\beta^{\mathrm{D} 849 \mathrm{~V}}$ are designated $\mathrm{K}$, for the kinase domain mutation. We thus generated four offspring genotypes: Stat ${ }^{+/}{ }^{-}$referred to here as $\left.\mathrm{S}^{+/-}\right)$, Stat1 ${ }^{-1-}\left(\mathrm{S}^{-/-}\right)$, Pdgfrb ${ }^{+/ D 849 V}$ Stat $^{+/-}\left(\mathrm{KS}^{+/-}\right)$, and $P d g f r b^{+/ D 849 V}$ Stat1 ${ }^{-/-}\left(K^{-/-}\right)$(Fig. 1C). Importantly, while Stat1-deficient mice are nonresponsive to IFNs, they do not exhibit obvious growth or survival phenotypes unless challenged (Durbin et al. 1996; Meraz et al. 1996). Marginally increased bone formation has also been reported in $S^{-/-}$mice compared with $S^{+/+}$mice (Sahni et al. 2001; Kim et al. 2003). As expected from previous studies, $S^{+/-}$ and $S^{-1-}$ mice did not have obvious phenotypes. Therefore, we focused subsequent analysis on $\mathrm{KS}^{+/-}$and $\mathrm{KS}^{-/-}$ mice. $\mathrm{KS}^{+/-}$mice were underweight after day 7 and died in the third week postnatal, but, interestingly, young $\mathrm{KS}^{-/-}$mice were normal in overall appearance (Fig. 1D-F). Therefore, juvenile lethality depends on STAT1. Importantly, even though $\mathrm{KS}^{-/-}$mice appeared normal at 3 wk of age, they succumbed to early death at $\sim 8 \mathrm{wk}$ (Fig. 1F).

\section{PDGFR $\beta$-STAT1 signaling drives autoinflammation}

STAT1 was constitutively phosphorylated in VSMCs from Pdgfrb ${ }^{+/ D 849 V}$ mice (He et al. 2015). To determine whether this occurs in other cell types, we used PDGFtreated primary dermal fibroblasts (DFs) from the four genotypes of mice described above. STAT1 was not detected in $S^{-/-}$and $K S^{-/-}$DFs. STAT1 became phosphorylated in $S^{+/-}$DFs only after exposure to PDGF-BB but was constitutively phosphorylated in $K S^{+/-}$DFs (Fig. 2A, lane 9). Many STAT1 target genes are ISGs, a broad class of IFN- inducible genes that includes chemokines (Cc12, Cxc19, $C x c 110$, and $C x c 111)$, antigen processing and antigen presentation machinery ( $P$ smb8 and $B 2 \mathrm{~m})$, antiviral response factors (Mx1 and Ifi27), and transcription factors (Irf1 and Stat1 itself). Unstimulated $\mathrm{KS}^{+/-}$DFs overexpressed several ISGs (Cxcl10, Psmb8, Mx1, Irf1, and Ifi27) (Supplemental Fig. S1), but ISG expression in $K S^{-/-}$DFs was comparable with $S^{+/-}$DFs. This demonstrates that PDGFR $\beta^{\mathrm{D} 849 \mathrm{~V}}$ activates STAT1 and thereby induces ISG expression in DFs.

We also monitored ISG expression in inguinal white adipose tissue (ingWAT), a subcutaneous fat depot that atrophies in Sox2-Cre Pdgfrb ${ }^{+/ D 849 V}\left(\mathrm{KS}^{+/+}\right)$mice /Olson and Soriano 2011). Stat1 was overexpressed in $\mathrm{KS}^{+/-}$compared with $\mathrm{S}^{+/-}$fat (Fig. 2B). B2m, Ccl2, Cxc19, Cxc110, and Cxcl11 were also overexpressed in $\mathrm{KS}^{+/-}$fat, but their expression in $\mathrm{KS}^{-/-}$was comparable with $S^{+/-}$and $S^{-/-}$fat (Fig. 2B,C). Next, we used flow cytometry to quantify the infiltration of $\mathrm{CD}_{4} 5^{+}$leukocytes into the tissue. $\mathrm{KS}^{+/-}$fat contained more cells overall compared with other genotypes, and a greater percentage of these cells were CD $45^{+}$leukocytes. Mirroring ISG expression, full deletion of Stat1 in $\mathrm{KS}^{-/-}$mice reduced leukocyte infiltration to the level of $S^{+/-}$and $S^{-/-}$mice (Fig. 2D,E). Histological changes in the fat pad also tracked ISG expression, as $\mathrm{KS}^{+/-}$fat at day 14 had an atrophied appearance with small adipocytes and abundant stromal cells and leukocytes, but $\mathrm{KS}^{-1-}$ was indistinguishable from $S^{+/-}$or $S^{-/-}$fat (Fig. 2F). Taken together, these data demonstrate that STAT1 is required for PDGFR $\beta$-driven autoinflammation characterized by ISG up-regulation and leukocyte infiltration into peripheral tissues. 

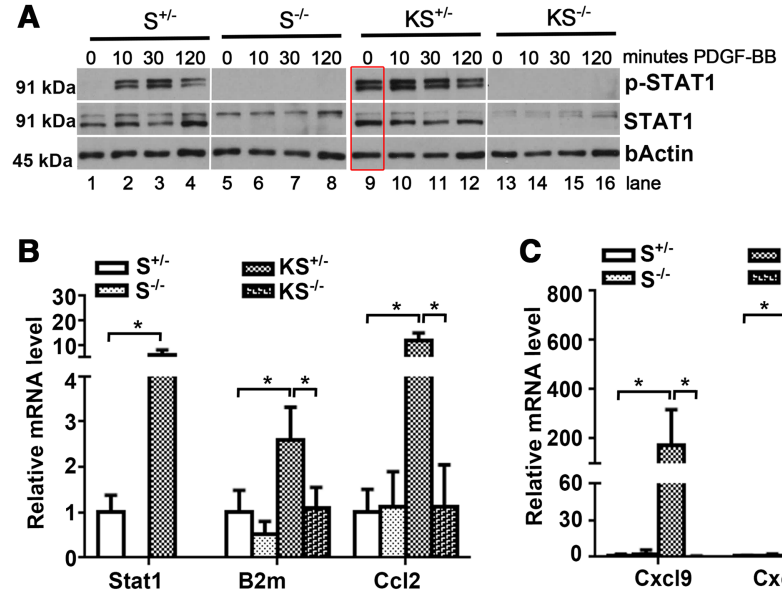

D
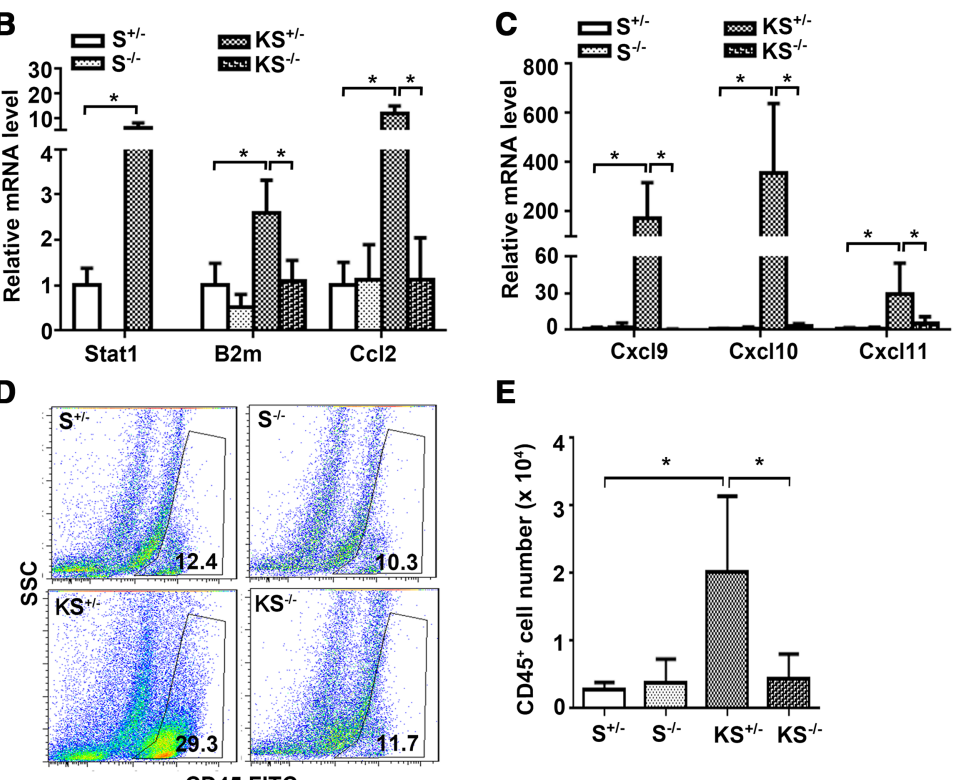

E

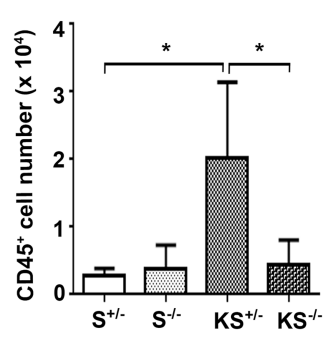

F
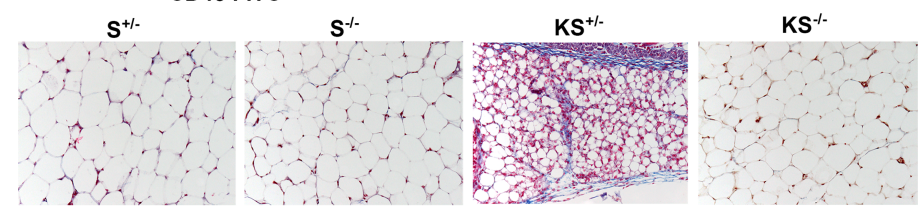

Figure 2. PDGFR $\beta$ drives autoinflammation by activating STAT1. (A) STAT1 expression and Y701 phosphorylation in primary DFs after $24 \mathrm{~h}$ in DMEM $+0.1 \%$ serum and stimulation with PDGF-BB. Data are representative of three experiments. The red box highlights constitutive STAT1 phosphorylation. Note that the weak top band in the total STAT1 blot is nonspecific. $(B, C)$ Fold change in ISG mRNA levels in inguinal white adipose tissue (ingWAT) from 14-d-old mice by quantitative RT-PCR (qRT-PCR) with normalization to Gapdh. $n$ $=3$ mice per genotype. $(D)$ Representative flow cytometry plots of $\mathrm{CD}^{+} 5^{+}$leukocytes in ingWAT from 14-d-old mice of the indicated genotypes. Numbers in the bottom right corner of each plot indicate the percentage of $\mathrm{CD} 45^{+}$cells among total cells analyzed. $(E)$ Quantification of $\mathrm{CD} 45^{+}$leukocyte absolute number measured by flow cytometry. $n=3$ mice per genotype. $(F)$ Histological analysis of trichrome-stained ingWAT from 14-d-old

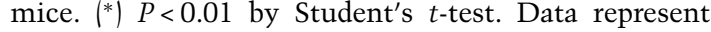
mean $\pm \mathrm{SD}$

\section{STAT1 suppresses PDGFR $\beta$ expression and signaling in DFs}

The rescue of lethal wasting by Stat 1 knockout prompted us to investigate PDGFR $\beta$ expression and downstream signaling in cells from the affected mice. PDGFR $\beta$ mRNA and protein levels were significantly reduced in $\mathrm{KS}^{+/-}$ DFs compared with $S^{+/-}$and $S^{-/-}$DFs (Fig. 3A). This is consistent with previous microarray data showing a $50 \%$ reduction of $P d g f r b$ expression in $P d g f r b^{+/ D 849 V}$ pericytes compared with wild type (GSE29284) (Olson and Soriano 2011). However, complete Stat1 deletion fully restored mRNA levels and partially restored protein levels in $\mathrm{KS}^{-/-}$DFs (Fig. 3A,B). PDGFR $\beta$ is constitutively autophosphorylated in PDGFR $\beta^{\mathrm{D} 849 \mathrm{~V}}$-expressing embryonic fibroblasts and adult VSMCs (Olson and Soriano 2011; He et al. 2015). To investigate whether Stat1 deletion has an effect on PDGFR $\beta$ autophosphorylation, we serum-starved DFs and examined phosphorylation under basal conditions or after PDGF treatment. As expected, PDGFR $\beta$ phosphorylation was low in $S^{+/-}$and $S^{-/-}$DFs under serum-starved conditions. Basal phosphorylation was increased in $\mathrm{KS}^{+/-}$and $\mathrm{KS}^{-/-}$DFs compared with $\mathrm{S}^{+/-}$and $\mathrm{S}^{-/-}$DFs but was significantly stronger in $\mathrm{KS}^{-/-}$ compared with $\mathrm{KS}^{+/-}(P<0.01)$ (Fig. 3C). PDGF induced strong PDGFR $\beta$ phosphorylation in all genotypes, with a trend toward the highest response in $\mathrm{KS}^{-/-}$cells. These data indicate that STAT1 negatively regulates $P d g f r b$ gene expression and signaling.

We showed previously that PLC $\gamma$ was constitutively phosphorylated in $\mathrm{KS}^{+/+}$mouse embryonic fibroblasts, while two other PDGF pathway effectors, Akt and Erk1/ 2, were phosphorylated only in response to PDGF /Olson and Soriano 2011). We asked whether Stat1 deletion alters these events. Once again, the phosphorylation of Akt and Erk1/2 was PDGF-dependent in all DF genotypes (Supplemental Fig. S2). Also, as shown previously, PLC $\gamma$ was constitutively phosphorylated in $\mathrm{KS}^{+/-}$DFs compared with $S^{+/-}$DFs (Fig. 3D, lane 5 vs. lane 1), but PDGF-induced phosphorylation was blunted in $\mathrm{KS}^{+/-}$compared with other genotypes (Fig. 3D, lane 6 vs. lane 2). Furthermore, Stat1 deletion resulted in stronger basal PLC $\gamma$ phosphorylation in $\mathrm{KS}^{-/-}$DFs compared with $\mathrm{KS}^{+/-}$DFs (Fig. 3D, lane 7 vs. lane 5). We also examined STAT3 and STAT5, two other PDGF-regulated STATs, and found them constitutively phosphorylated in serum-starved $\mathrm{KS}^{+/-}$and $K S^{-/-}$DFs compared with $S^{+/-}$and $S^{-/-}$(Fig. 3E,F). Therefore, PLC $\gamma$ phosphorylation by PDGFR $\beta^{\mathrm{D} 849 \mathrm{~V}}$ is enhanced by Stat1 deletion, but there is no effect on constitutive STAT3/5 phosphorylation.

Taken together, these results demonstrate that STAT1 suppresses the gain-of-function signaling exerted by 

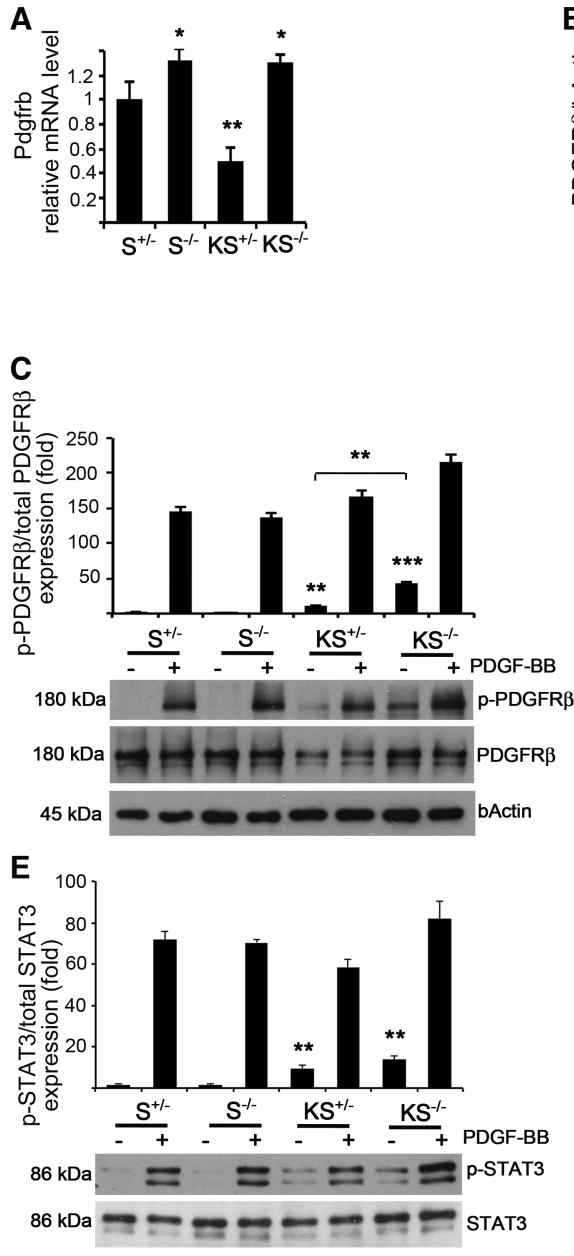
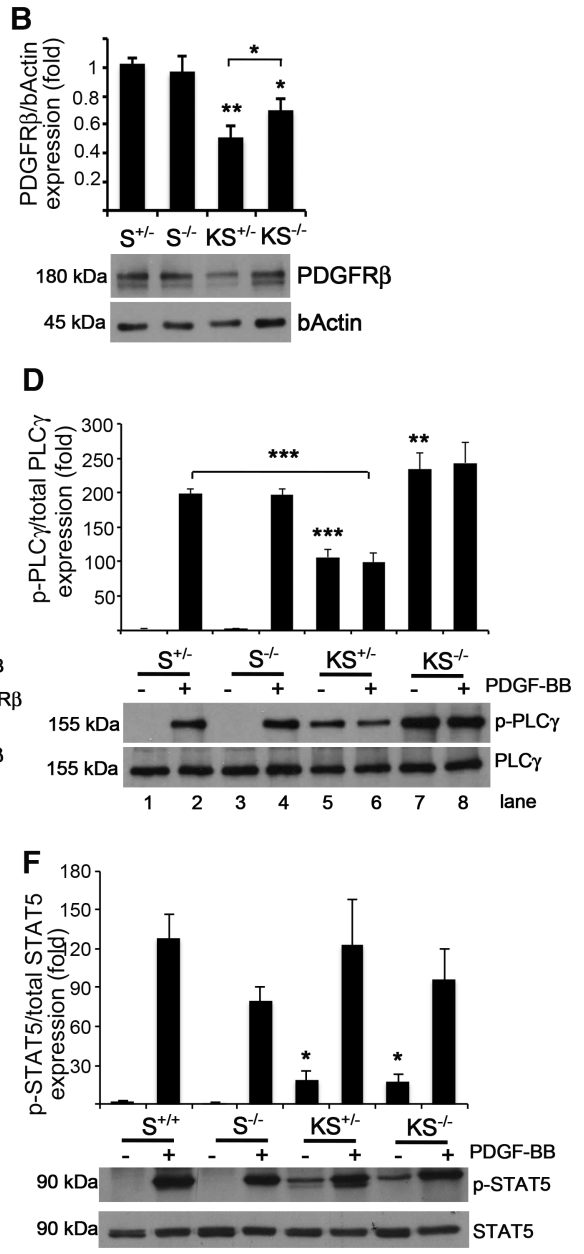

Figure 3. STAT1 suppresses PDGFR $\beta$ expression and signaling in DFs. $(A)$ Fold change in Pdgfrb mRNA in DFs by qRT-PCR with normalization to Gapdh. $\mathrm{S}^{+-}$expression levels were set as onefold. (*) $P<0.05$ $\mathrm{S}^{-/-}$or $\mathrm{KS}^{-/-}$versus $\mathrm{S}^{+/-}$; $\left(^{* *}\right) P<0.01 \mathrm{KS}^{+/-}$ versus $\mathrm{S}^{+/-} . n=3$ biological replicates per genotype. $(B)$ Fold change in PDGFR $\beta$ protein in DFs normalized to bActin. $\mathrm{S}^{+/-}$levels were set as onefold. $\left(^{*}\right) P<0.05 \mathrm{KS}^{-/-}$versus $\mathrm{S}^{-/-}$and $\mathrm{KS}^{+/-}$versus $\mathrm{KS}^{-/-}$; $\left(^{* *}\right) P<0.01$ $\mathrm{KS}^{+/-}$versus $\mathrm{S}^{+/-} . n=8$ blots; a representative blot is shown. $(C-E)$ DFs were starved in DMEM $+0.1 \%$ serum for $24 \mathrm{~h}$ and then stimulated with PDGF-BB for $10 \mathrm{~min}$. Unstimulated $\mathrm{S}^{+/-}$DFs were set as onefold. $n=3$ blots; a representative blot is shown. $(C)$ Fold change in p-PDGFR $\beta$ phosphorylation normalized to total PDGFR $\beta$. $\left(^{* *}\right) P<0.01$ $\mathrm{KS}^{+/-}$basal versus $\mathrm{S}^{+/-}$; $\left.{ }^{* * *}\right) P<0.001 \mathrm{KS}^{-/-}$ basal versus $\mathrm{S}^{-/-}$basal basal and $\mathrm{KS}^{+/-}$basal versus $\mathrm{KS}^{-/-}$basal. $(D)$ Fold change in PLC $\gamma$ phosphorylation normalized to total PLC $\gamma$. $\left.{ }^{* *}\right) P<0.01 \mathrm{KS}^{-1-}$ basal versus $\mathrm{KS}^{+/-}$basal; $\left.{ }^{* * *}\right) P<0.001 \mathrm{KS}^{+/-}$basal versus $\mathrm{S}^{+/-}$basal and $\mathrm{KS}^{+/-}$stimulated versus $\mathrm{S}^{+/-}$stimulated. (E) Fold change in STAT3 phosphorylation normalized to total STAT3. $\left(^{* *}\right) P<0.01$ $\mathrm{KS}^{+/-}$basal versus $\mathrm{S}^{+/-}$basal and $\mathrm{KS}^{-/-}$basal versus $\mathrm{S}^{-/}$basal. $(F)$ Fold change in STAT5 phosphorylation normalized to total STAT5. $\left.{ }^{*}\right) P<0.05 \mathrm{KS}^{-/-}$basal versus $\mathrm{S}^{-/-}$ basal and $\mathrm{KS}^{+/-}$basal versus $\mathrm{S}^{+/-}$basal. Statistical tests were by paired $(B)$ or unpaired $(A$, $C-F$ ) Student's $t$-test. Data represent mean \pm SEM.
PDGFR $\beta^{\mathrm{D} 849 \mathrm{~V}}$. The mechanism of suppression might involve STAT1-dependent ISGs that exert negative feedback on upstream signaling. For example, the suppressor of cytokine signaling (SOCS) family of proteins consists of negative regulators of cytokine and some growth factor signaling cascades (Linossi et al. 2013; Kazi et al. 2014). We analyzed the expression of eight SOCS members (SOCS1-7 and CIS) in cultured DFs. Socs4-7 expression did not differ greatly between genotypes. However, Socs1 and Socs3 exhibited a trend of up-regulation only in $\mathrm{KS}^{+/-} \mathrm{DFs}$, suggestive of regulation like other ISGs (Supplemental Fig. S3). Therefore, if any SOCS proteins mediate negative feedback on PDGFR $\beta$, SOCS1 and SOCS3 would be the best candidates. In contrast, Socs2 and Cis were up-regulated in $\mathrm{KS}^{+/-} \mathrm{DFs}$ (approximately threefold) and further overexpressed in $K S^{-/-}$DFs $(\sim 40$-fold and $\sim 10-$ fold, respectively) (Supplemental Fig. S3). This suggests changes in STAT-regulated transcription, where STAT1 opposes the function of other pathways/effectors that stimulate Socs2 and Cis expression (potentially STAT3/ 5). The SOCS proteins exert negative feedback on cytokine receptors by inhibiting kinase activity or mediating receptor degradation. However, further studies are needed to determine whether and under what conditions PDGFR $\beta$ may be a target of SOCS negative feedback.
STAT1 controls skin and adipose tissue phenotypes linked to PDGFR $\beta$ gain of function

Increased PDGFR $\beta$ signaling in $K S^{-/-}$DFs suggested that $K S^{-/-}$mice might develop novel phenotypes related to increased signaling in the absence of STAT1. For instance, PDGF signaling stimulates fibroblast proliferation and extracellular matrix secretion, which can lead to organ fibrosis (Bonner 2004; Andrae et al. 2008). To identify new phenotypes in $\mathrm{KS}^{+/-}$or $\mathrm{KS}^{-/-}$mice, we first examined the skin, focusing on the collagen-rich upper dermis and the underlying dermal WAT (dWAT) (Driskell et al. 2014). The dorsal skins of $S^{+/-}$and $S^{-/-}$littermates were indistinguishable. At $3 \mathrm{wk}$ of age, $\mathrm{KS}^{+/-}$skin was very thin without obvious fat, but $K S^{-/-}$skin exhibited an opposite phenotype with a thickened upper dermis (Fig. 4A, double arrow). Furthermore, the $K S^{-1-}$ dWAT exhibited areas of interstitial collagen accumulation and expansion of stromal cells between adipocytes (Fig. 4A, circle). To quantify fibrosis, we measured the upper dermal thickness from the epidermal-dermal junction to the dermalfat junction. By this measure, the $K S^{+/-}$dermis was significantly thinner than that of $S^{+/-}$, and there was significant dermal thickening in 3-wk-old $K S^{-/-}$mice (Fig. 4B). Moreover, by 8 wk of age, the $K S^{-/-}$upper dermis had thickened 
A
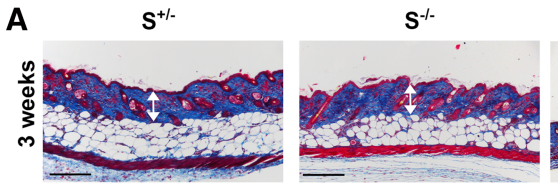

3 weeks

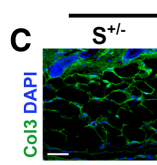

D
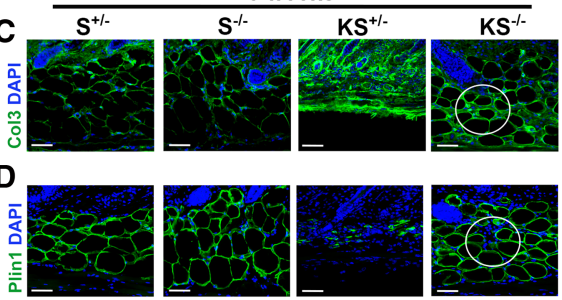

E
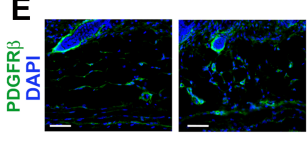
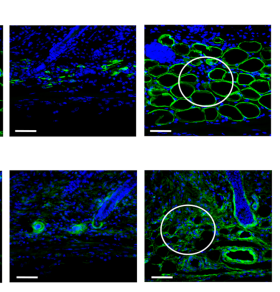

$\mathrm{KS}^{+/-}$

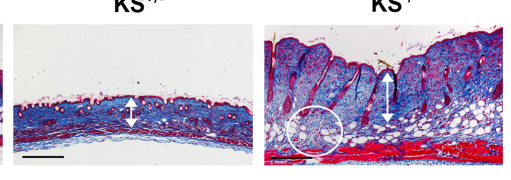

B

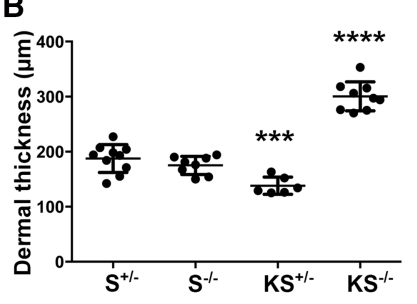

so much that it replaced dWAT, demonstrating the progressive nature of the fibrosis (Supplemental Fig. S4).

We stained 3-wk-old skin for collagen 3 (Col3) to mark areas of fibrosis or for perilipin (Plin1) to mark adipocytes. Consistent with histological analysis, abundant $\mathrm{Col} 3$ protein was detected in the $\mathrm{KS}^{-/-}$dermal fat, particularly in the expanded interstitial space between individual adipocytes (Fig. 4C, circle). Col3 staining in the $S^{+/-}$and $S^{-/-}$fat was markedly lower than $\mathrm{KS}^{-/-}$. There was high $\mathrm{Col} 3$ staining throughout the $\mathrm{KS}^{+/-}$dermis, probably due in part to compression of the atrophic tissue. Plin1 stains the cytoplasm around the central lipid droplet of each adipocyte, which highlights a ring-like morphology for each adipocyte in $\mathrm{S}^{+-}, \mathrm{S}^{-/-}$, and $K S^{-/-}$skin. The atrophied $\mathrm{KS}^{+/-}$skin contained very small Plin $1^{+}$cells with a fibroblast-like morphology and no obvious lipid droplet (Fig. 4D). Interestingly, highly fibrotic skin of 8-wk-old $\mathrm{KS}^{-/-}$ mice also contained very small Plin $1^{+}$cells still embedded in the lower dermis (Supplemental Fig. S5A). Therefore, in both atrophied $\mathrm{KS}^{+/-}$skin and fibrotic $\mathrm{KS}^{-/-}$skin, Plin1 ${ }^{+}$ adipocytes persist without obvious lipid droplets. Since STAT1 suppressed PDGFR $\beta$ expression and signaling (Fig. 3), we examined PDGFR $\beta$ expression in skin. In all genotypes, PDGFR $\beta$ was highly expressed in the hair follicle dermal sheath and in mural cells surrounding blood vessels. However, exclusively in $\mathrm{KS}^{-/-}$skin, there was strong PDGFR $\beta$ expression in the fibroblast-like interstitial cells located in dermal fat (Fig. 4E, circle).

Next, we examined other fat depots, which generally exist in the form of white fat specialized for lipid storage or brown adipose tissue (BAT) specialized for thermogenesis. Like the skin, all tissues from $S^{+/-}$and $S^{-/-}$mice had similar morphology. The remnant of $\mathrm{KS}^{+/-}$ingWAT from 3-wk-old mice contained only stromal vascular cells without obvious adipocytes (Fig. 5A). The $K S^{-/-}$ingWAT at 3 wk appeared grossly normal, but some perivascular fibrosis was apparent by trichrome stain (Fig. 5A arrows). By $8 \mathrm{wk}, \mathrm{KS}^{-1-}$ ingWAT was highly fibrotic (Fig. 5B). Like the skin, Plin $1^{+}$fibroblast-like cells were still detectable in the atrophied remnant of $\mathrm{KS}^{+/-}$ingWAT at 3 wk (Supplemental Fig. S5B) and also in the fibrotic remnant of
$\mathrm{KS}^{-1-}$ ingWAT at 8 wk (Supplemental Fig. S5C). Perigonadal WAT (pWAT) displayed a similar trend of rapid atrophy in $\mathrm{KS}^{+/-}$mice and slower fibrotic remodeling in $\mathrm{KS}^{-/-}$mice (Fig. 5C,D). In contrast, BAT was resistant to atrophy in $\mathrm{KS}^{+/-}$mice, and minimal perivascular fibrosis in $K^{-l-}$ BAT was not accompanied by overt tissue remodeling even by $8 \mathrm{wk}$ (Fig. 5E,F). Therefore, WAT is highly sensitive to elevated PDGFR $\beta$ signaling, while BAT is resistant. Interestingly, WAT-selective remodeling was also reported in mice with elevated PDGFR $\alpha$ signaling (Sun et al. 2017). In summary, PDGFR $\beta-S T A T 1$ signaling causes atrophy of the dermis and WAT, but, in the absence of STAT1, PDGFR $\beta^{\mathrm{D} 849 \mathrm{~V}}$ causes fibroproliferative replacement of WAT with collagen-rich matrix (Fig. 5G).

\section{VSMC hyperplasia in Pdgfrb ${ }^{+/ \mathrm{D} 849 \mathrm{~V}}$ aortas is STAT1- independent}

PDGFR $\beta^{\text {D849V }}$ causes VSMC hyperplasia that leads to arterial stiffening and gradual outward remodeling of the aorta (Olson and Soriano 2011). To determine whether STAT1 is required for PDGFR $\beta^{\mathrm{D} 849 \mathrm{~V}}$-induced VSMC hyperplasia, we generated a cohort of KS mutants with VSMC-selective Sm22a-Cre. This Cre driver is advantageous because mice survive up to 1 yr when PDGFR $\beta^{\text {D849V }}$ expression is restricted to VSMCs. At $6 \mathrm{wk}$ of age, the $\mathrm{KS}^{+/-}$and $\mathrm{KS}^{-/-}$aortas were similarly dilated and dense with hyperplastic VSMCs compared with $S^{+/-}$and $S^{-/-}$ aortas (Supplemental Fig. S6A). $\mathrm{KS}^{+/-}$aortas exhibited perivascular inflammation (Supplemental Fig. S6A, arrows), which was also shown previously in $\mathrm{KS}^{+/+}$aortas (He et al. 2015). As expected, inflammation was rescued from $\mathrm{KS}^{-/-}$aortas but was replaced by fibrosis of the adventitia (Supplemental Fig. S6A, asterisks). We also stained for the contractile VSMC markers aSMA, Sm22a, and SMMHC. These markers were down-regulated in $\mathrm{KS}^{+/-}$and $\mathrm{KS}^{-/-}$aortas compared with $\mathrm{S}^{+/-}$and $\mathrm{S}^{-/-}$ (Supplemental Fig. S6B), indicating a loss of contractile phenotype. These morphological and molecular changes show that PDGFR $\beta^{\mathrm{D} 849 \mathrm{~V}}$ induces VSMC hyperplasia independently of STAT1. 


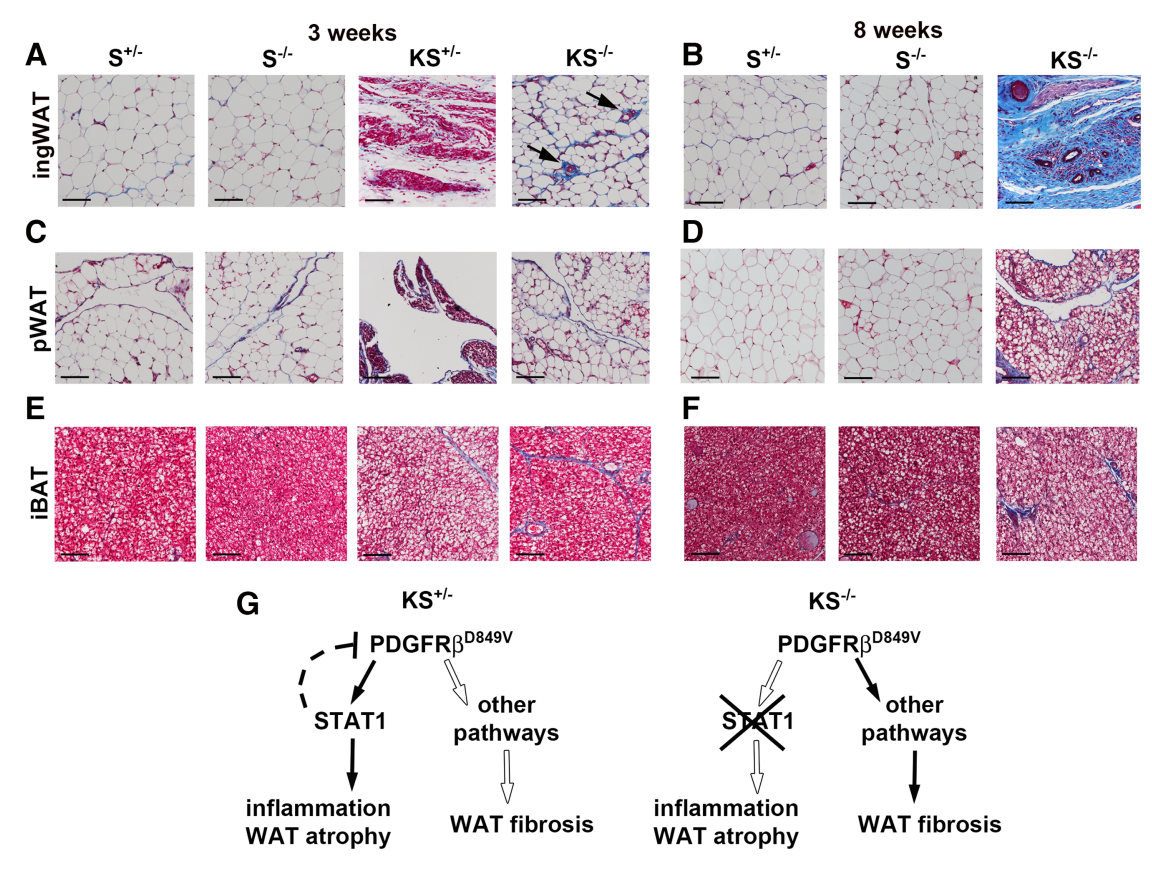

Figure 5. Atrophy or fibrotic remodeling of WAT but not BAT. $(A-F)$ Trichrome-stained ingWAT, pWAT, and iBAT at 3 or $8 \mathrm{wk}$ of age. Arrows in $A$ indicate perivascular fibrosis. Bar, $200 \mu \mathrm{m}$. (G) Graphical summary of the skin/WAT phenotype, where $\mathrm{KS}^{+/-}$ WAT undergoes STAT1-dependent atrophy by 3 wk of age, and $\mathrm{KS}^{-1-}$ WAT undergoes STAT1-independent fibroproliferative remodeling by 8 wk of age.

\section{STAT1 modulates PDGFR $\beta^{D 849 V}$-driven skeletal phenotypes}

Skeletal phenotypes have not been shown in Pdgfrb ${ }^{+/ D 849 V}$ mice but occur in humans with PDGFRB gain-of-function mutations. To address this discrepancy, we first analyzed skeletons by whole-mount staining at birth. At this time, we did not find consistent defects in $\mathrm{KS}^{+/-}$or $\mathrm{KS}^{-/-}$skeletons compared with $S^{+/-}$and $\mathrm{S}^{-/-}$, but $\mathrm{KS}^{+/-}$ribcages were sometimes narrower (Supplemental Fig. S7). Instead, consistent differences were noted at 3 wk of age: By this time, $S^{+/-}$and $S^{-/-}$calvaria were mineralized and stained with Alizarin red, but $\mathrm{KS}^{+/-}$calvaria were poorly mineralized and incompletely stained (Fig. 6A). Intriguingly, $\mathrm{KS}^{-1-}$ calvaria exhibited a granular staining pattern suggestive of internal changes (Fig. 6B). Upon sectioning the center of the calvaria, we found that the $\mathrm{KS}^{-/-}$skulls had marrow-filled channels throughout the bone (Fig. 6C); similar channels were seen only near the sutures of 3 -wk-old $S^{+/-}$and $S^{-1-}$ calvaria (Supplemental Fig. S8). In marked contrast to $\mathrm{KS}^{-/-}$calvaria, $\mathrm{KS}^{+/-}$calvaria were very thin and lacked marrow-filled channels (Fig. 6C,D). $S^{-/-}$calvaria were slightly thicker than $S^{+/-}$calvaria, consistent with previous reports (Xiao et al. 2004). In all genotypes, PDGFR $\beta$ was expressed in the sagittal suture mesenchyme, where skeletal stem cells reside (Zhao et al. 2015), plus broad expression in the periosteum, dura, and endosteum, which are regions populated by more differentiated osteoblast lineage cells (Supplemental Fig. S8).

The ribcage was also altered in 3-wk-old PDGFR $\beta^{\mathrm{D} 849 \mathrm{~V}}$ expressing mice. Each rib has a dorsal bony segment attached to the spine and a ventral cartilaginous segment attached to the sternum. A growth plate forms at the bone-cartilage interface in the middle of each rib. $\mathrm{KS}^{+/-}$ ribs were thin, and bone was poorly mineralized (Fig. 6E;
Supplemental Fig. S9|. However, in $K S^{-/-}$ribs, the cartilage and bone near the growth plate were slightly enlarged, forming a noticeable bulge (Fig. 6E; Supplemental Fig. S9). $\mathrm{KS}^{-1-}$ ribs also typically displayed ridges of nonmineralized tissue over the groove of Ranvier (Fig. 6E arrows). This groove in the perichondrium forms at the periphery of the growth plate of most long bones and runs circumferentially around the bone. It is believed to harbor progenitor cells that govern circumferential growth of cartilage and the formation of periosteum around the growth plate (Shapiro et al. 1977; Karlsson et al. 2009; Yang et al. 2013). Histological analysis of this region failed to show consistent differences between $S^{+/-}$and $S^{-/-}$bones, but the groove of $\mathrm{KS}^{+/-}$ribs was typically shallow and hypocellular (Fig. 6F, boxed area enlarged below). In contrast, the groove of $K S^{-1-}$ ribs was hyperplastic with an expansion of fibrous tissue superior to the groove (Fig. 6F), corresponding to the nonmineralized ridge of tissue noted by whole mount (Fig. 6E arrows). There was a slight but statistically significant increase in growth plate width in $S^{-/-}$ ribs compared with $S^{+/-}$, without a difference in height (Fig. 6G,H). The $\mathrm{KS}^{-/-}$growth plates were significantly enlarged. The $\mathrm{KS}^{+/-}$growth plates appeared disorganized and lens shaped, with an average width intermediate between $\mathrm{S}^{-/-}$and $\mathrm{KS}^{-/-}$. Therefore, taking together the skull and rib defects, the pattern of bone phenotypes corresponds with the fat and skin phenotypes, where the $K S^{+/-}$tissues exhibit degenerative features, and the $\mathrm{KS}^{-/-}$tissues exhibit overgrowth. Poor mineralization can result from inadequate levels of crucial metabolites, but we did not find significant differences in serum phosphate, calcium, or vitamin $\mathrm{D}$ among the four genotypes at 3 wk of age (data not shown).

In a cohort of $S^{+/-}, S^{-/-}$, and $K S^{-/-}$mice at 6-8 wk of age, $\sim 75 \%$ of the $\mathrm{KS}^{-1-}$ mice were overgrown /defined as $>25 \mathrm{~g}$ or at least two standard deviations above the average 


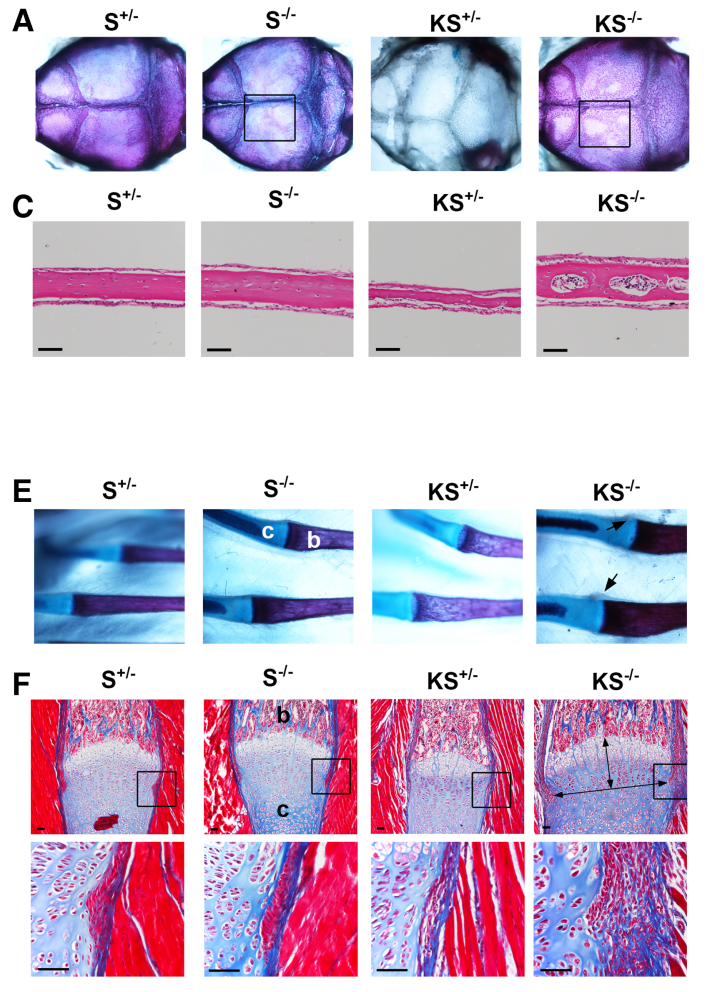

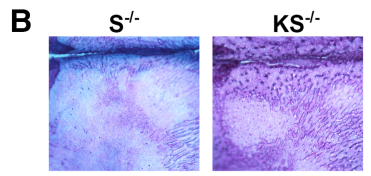
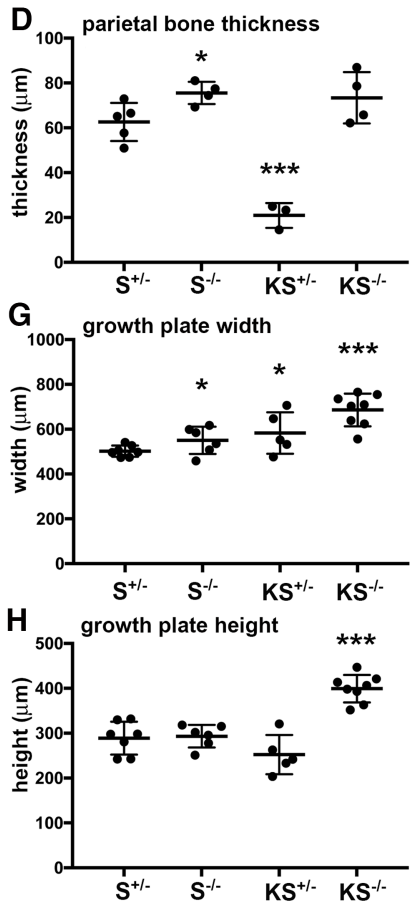

Figure 6. STAT1 modulates PDGFR $\beta^{\mathrm{D} 849 \mathrm{~V}}$. driven skeletal defects. (A) Whole-mount analysis of 3-wk-old calvaria stained with Alizarin red/Alcian blue. $(B)$ Boxed areas from $A$ enlarged to show a granular staining pattern in $\mathrm{KS}^{-/-}$. (C) Parietal bones at $3 \mathrm{wk}$ showing a hematoxylin and eosin-stained cross-section near the center of the bone. Bar, $50 \mu \mathrm{m}$. (D) Parietal bone thickness. Data points represent individual animals. (*) $P<0.05 \mathrm{~S}^{-/-}$versus $\mathrm{S}^{+/-}$; (***) $P<0.001$ $\mathrm{KS}^{+/-}$versus $\mathrm{S}^{+/-}$. (E) Whole-mount analysis of 3-wk-old fourth and fifth ribs at the costochondral junction stained with Alizarin red/ Alcian blue. (c) Cartilage; (b) bone. Arrows indicate the ridge of nonmineralized tissue overlying the perichondrial groove in $\mathrm{KS}^{-/-}$ ribs. $(F)$ Trichrome-stained cross-sections through the growth plate of the fourth or fifth rib. The perichondrial groove is boxed in the top panels and is shown at high magnification in the bottom panels. (c) Cartilage; (b) bone. Arrows indicate the axes measured in $G$ and $H$. Bar, $50 \mu \mathrm{m}$. (G) Growth plate width measured at the level of the perichondrial groove. Data points represent the mean of two to four ribs per individual mouse (fourth and fifth ribs, right and left sides). (*) $P<0.05 \mathrm{~S}^{-1-}$ versus $\mathrm{S}^{+-}$and $\mathrm{KS}^{+/-}$versus $\mathrm{S}^{+/-} ;\left(^{* * *}\right) P<0.001 \mathrm{KS}^{-/-}$versus $\mathrm{S}^{+/-}$by Student's $t$-test. $(H)$ Growth plate height measured from the bone-cartilage border to the level of the groove. Data points represent the mean of two to four ribs per mouse (fourth and fifth ribs, right and left sides). (***) $P<$ $0.001 \mathrm{KS}^{-/-}$versus $\mathrm{S}^{+/-}$. All statistics by Student's $t$-test. Data represent mean $\pm \mathrm{SD}$.

weight of controls) (Supplemental Fig. S10A,B). Since $K S^{-1-}$ mice are not obese, most of the increase in weight should be due to overgrowth of the skin, connective tissue, and skeleton. $\mathrm{KS}^{-/-}$mice also developed severe kyphosis and abnormally long ribs that caused the sternum to protrude (Supplemental Fig. S10A,C). Moreover, after removing the skin, the $\mathrm{KS}^{-/-}$calvaria were red instead of the usual pale pink (Supplemental Fig. S11A). Sectioning revealed that the color change was due to a greatly expanded marrow area (Supplemental Fig. S11B), which extended the observations in three wk-old $\mathrm{KS}^{-/-}$calvaria (Fig. 6C). Therefore, the subtle skull and rib defects in 3wk-old $\mathrm{KS}^{-1-}$ mice presaged rapid skeletal overgrowth by 8 wk of age. In contrast, $K S^{+/-}$mice exhibited underdeveloped or atrophied skull and rib bones, which was already quite severe by $3 \mathrm{wk}$. It is clear from these data that PDGFR $\beta$ regulates skeleton growth, a process that is strongly modified by the STAT1 pathway.

\section{Canonical IFN signaling is not required for PDGFR $\beta^{D 849 V}$-driven wasting}

STAT1 is required for signaling by type I IFN (IFN $\alpha$ and IFN $\beta$ ) and type II IFN (IFN $\gamma)$. These cytokines exert potent antiviral and anti-proliferative effects on most cell types by binding to receptor complexes that include Ifnar1 (IFN $\alpha$ and IFN $\beta$ receptor subunit 1) or Ifngrl (IFN $\gamma$ recep- tor subunit 1). Excessive IFN signaling is detrimental. Mice and rats treated with IFN for the first week of life suffer lethal wasting (Gresser et al. 1980), which bears some similarity to $\mathrm{KS}^{+/+}$and $\mathrm{KS}^{+/-}$mice. A different case is Trex $^{-/-}$mice, which have constitutive activation of a cytosolic viral nucleic acid-sensing pathway that results in up-regulation of ISGs and lethal autoinflammation (Stetson et al. 2008). Importantly, Trex ${ }^{-/-}$mice are rescued by deletion of Ifnar1, which proves that type I IFN signaling is central to pathology. Excessive IFN production is postulated to be directly involved in human genetic diseases called type I interferonopathies, in which autoinflammation is initially triggered by mutations in TREX or other cytosolic viral sensors (Crow et al. 2006; Crow and Manel 2015). It is unclear whether PDGFR $\beta^{\text {D849V }}$ induces canonical IFN signaling or simply hijacks the pathway downstream through STAT1. We never detected increased IFN mRNA/protein in biological samples from PDGFR $\beta^{\text {D849V }}$-expressing mice (Olson and Soriano 2011; He et al. 2015). Nevertheless, even trace levels of IFN can induce cell responses. To directly evaluate the role of IFN receptor signaling in PDGFR $\beta^{\mathrm{D} 849 \mathrm{~V}}$-expressing mice, we generated cohorts with Sox2-Cre for activation of PDGFR $\beta^{\mathrm{D} 849 \mathrm{~V}}$ and deletion of either Ifnar1 (designated A) or Ifngr1 (designated G). Complete deletion of Ifnar1 improved the median survival of $K A^{-/-}$pups by $4 \mathrm{~d}$ compared with $K A^{+/-}(P<0.05)$, but wasting was still evident, 
and no pups survived more than 3 wk (Fig. 7A,B). Ifngr1 deletion had no effect on survival of $K G^{-/-}$pups compared with $\mathrm{KG}^{+/-}$(Fig. 7C,D). Since these genetic experiments failed to rescue autoinflammation-associated wasting, we conclude that IFNs themselves are not required. The small extension of life span in $K A^{-/-}$pups suggests that Ifnarl has a minor role in potentiating autoinflammation. Since tonic signaling through Ifnarl is needed to maintain the basal expression of STAT1 (Gough et al. 2012), Ifnar1 deletion may improve survival of $K A^{-/-}$mice by reducing initial levels of STAT1.

\section{Discussion}

How downstream pathways mediate the physiological and pathological effects of RTK signaling remains an open question. Here we addressed the function of the PDGFR $\beta-S T A T 1$ pathway, finding that gain-of-function PDGFR $\beta$ signaling activates STAT 1 and thereby induces autoinflammation and lethal wasting in young mice. It is noteworthy that $\mathrm{KS}^{+/-}$mice died in the third week postnatal because we reported previously that $K S^{+/+}$mice died in the second week (Olson and Soriano 2011). This difference is a good indication that juvenile lethality in $P d g f \mathrm{rb}^{+/ D 849 V}$ mice is highly dependent on Stat1 gene dosage. However, wasting and early lethality still occurred in Pdgfrb ${ }^{+/ D 849 V}$ mice lacking IFN signaling $\left(K A^{-/-}\right.$and $K G^{-/-}$mice), which shows that IFNs are not major drivers of these phenotypes. In addition, we showed that STAT1 suppresses PDGFR $\beta^{\text {D849V }}$ expression and signaling in dermal fibroblasts, PDGFR $\beta$-STAT1 promotes lipoatrophy and wasting via autoinflammation, STAT1 inhibits PDGFR $\beta^{\mathrm{D} 849 \mathrm{~V}}$-driven fibrosis of skin and fat, and STAT1 modulates highly penetrant PDGFR $\beta^{\mathrm{D} 849 \mathrm{~V}}$-driven skeletal phenotypes. We can infer that PDGFR $\beta$-regulated proteins besides STAT1 are the mediators of fibrosis and skeletal overgrowth in $\mathrm{KS}^{-/-}$mice. Our data point to PLC $\gamma$ as a good candidate to mediate fibrosis and over- growth because of enhanced phosphorylation in $\mathrm{KS}^{-/-}$ compared with $\mathrm{KS}^{+/-}$cells. STAT3 and STAT5 are also interesting candidates because they were constitutively phosphorylated and their heterodimerization profiles could change without STAT1 (Delgoffe and Vignali 2013). Future genetic studies will address their roles in PDGFR $\beta^{\mathrm{D} 849 \mathrm{~V}}$-driven phenotypes. Our finding that wasting or overgrowth phenotypes in $\mathrm{KS}^{+/-}$and $\mathrm{KS}^{-/-}$mice are differentially dependent on STAT1 highlights its role as a crucial mediator and modifier of PDGFR $\beta$ signaling.

Mutations in PDGFRB have been linked recently to Penttinen syndrome and Kosaki overgrowth syndrome, two rare genetic conditions that affect the skin, fat, and bones in distinct ways (Johnston et al. 2015; Takenouchi et al. 2015). Two mutations, V665A and P584R, have been characterized biochemically as gain-of-function mutations (Johnston et al. 2015; Arts et al. 2016), but functional evidence that elevated PDGFR $\beta$ signaling causes overgrowth or wasting of connective tissue was lacking. Our studies in $P d g f r b^{+/ D 849 V}$ mice reveal significant phenotypic overlap with humans. This is strong functional evidence that PDGFRB mutations are causal. This conclusion is further supported by the report of a patient with an $\mathrm{N} 666 \mathrm{H}$ gain-of-function mutation in PDGFRB and overlapping phenotypes with Penttinen syndrome and Kosaki overgrowth syndrome who developed clinical improvement when treated with imatinib, an inhibitor of several kinases, including PDGFR $\beta$ (Pond et al. 2017). Table 1 summarizes the phenotypic spectrum of $\mathrm{KS}^{+/-}$and $K S^{-/-}$mice and correspondence to phenotypes described in human $P D G F R B$-related syndromes. In the skeleton, $\mathrm{KS}^{+/-}$mice exhibit thin bones reminiscent of Penttinen syndrome, while $\mathrm{KS}^{-/-}$mice develop overgrowth during adolescence that aligns very well with Kosaki overgrowth syndrome. In the skin and fat, $K S^{+/-}$mice exhibit dermal wasting and lipoatrophy. Penttinen syndrome patients are described as having thin or translucent skin with prominent venous patterning plus lipoatrophy and a prematurely aged appearance. We show that $K S^{-/-}$mice develop

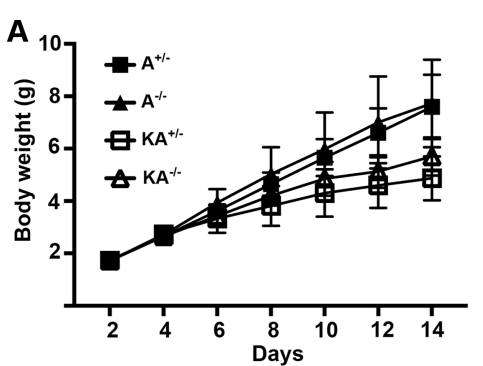

B

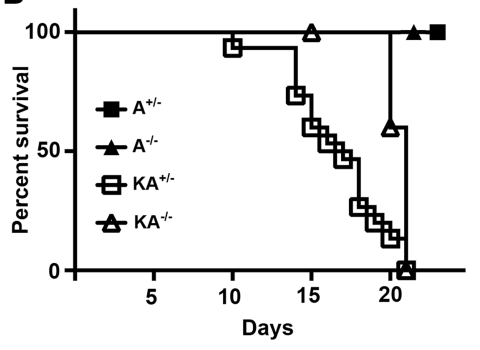

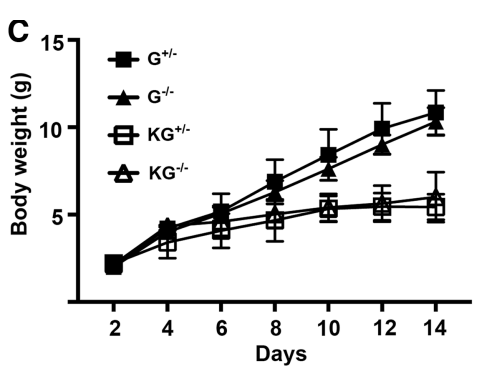

D

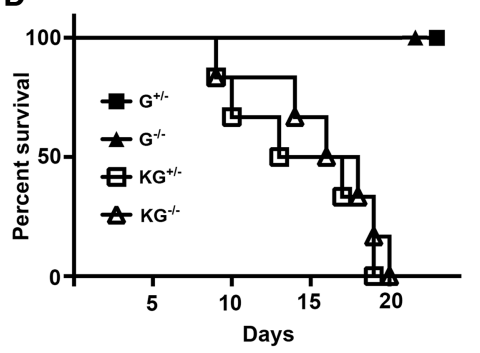

Figure 7. PDGFR $\beta^{\mathrm{D} 849 \mathrm{~V}}$-driven wasting does not require IFN signaling. $(A)$ Weight of pups with combinations of PDGFR $\beta^{\mathrm{D} 849 \mathrm{~V}}$ expression and Ifnar1 knockout, from 2 to 14 d old. $n=14 \mathrm{~A}^{+/-} ; n=4 \mathrm{~A}^{-1-} ; n=13 \mathrm{KA}^{+-}$; $n=4 \mathrm{KA}^{-1-}$. Data represent mean $\pm \mathrm{SD}$. $(B)$ Survival curve for cohorts of mice. The median survival of $\mathrm{KA}^{+/-}$and $\mathrm{KA}^{-/-}$pups is 17 and $21 \mathrm{~d}$, respectively, which is significant. $P<0.05$ by log-rank test. $n=17 \mathrm{~A}^{+/-} ; n=7$ $\mathrm{A}^{-1-} ; n=15 \mathrm{KA}^{+/-} ; n=6 \mathrm{KA}^{-/-} .(C)$ Weight of pups with combinations of PDGFR $\beta^{\mathrm{D} 849 \mathrm{~V}}$ expression and Ifngr1 knockout. $n=6 \mathrm{G}^{+/-} ; n=5 \mathrm{G}^{-/-} ; n=6 \mathrm{KG}^{+/-} ; n=5$ $\mathrm{KG}^{-/-}$. Data represent mean $\pm \mathrm{SD}$. (D) Survival curve for cohorts of mice, with no survival difference between $\mathrm{KG}^{+/-}$and $\mathrm{KG}^{-/-} . n=6 \mathrm{G}^{+/-} ; n=4 \mathrm{G}^{-/-} ; n=6 \mathrm{KG}^{+/-} ; n=$ $6 \mathrm{KG}^{-1-}$. 
Table 1. Phenotypes in $\mathrm{KS}^{+/-}$and $\mathrm{KS}^{-/-}$mutant mice compared with reports of humans with gain-of-function PDGFRB mutations

\begin{tabular}{|c|c|c|c|c|c|}
\hline Mouse phenotypes & $\begin{array}{l}\text { Mouse } \\
\text { genotype }\end{array}$ & $\begin{array}{l}\text { Role of } \\
\text { STAT1 }\end{array}$ & Human phenotypes & $\begin{array}{l}\text { Human } \\
\text { genotype }^{\mathrm{a}}\end{array}$ & References \\
\hline $\begin{array}{l}\text { Skeletal } \\
\text { degeneration }\end{array}$ & $K S^{+/-}$ & Promotes & $\begin{array}{l}\text { Thin calvaria and bones, acro- } \\
\text { osteolysis, osteopenia }\end{array}$ & V665A & Johnston et al. 2015 \\
\hline Skeletal overgrowth & $K S^{-/-}$ & Inhibits & $\begin{array}{l}\text { Skeletal overgrowth, thick calvaria } \\
\text { with diffuse granular pattern }\end{array}$ & P584R, W566R & $\begin{array}{l}\text { Takenouchi et al. 2015; } \\
\quad \text { Minatogawa et al. } 2017\end{array}$ \\
\hline $\begin{array}{l}\text { Lipoatrophy/ } \\
\text { wasting }\end{array}$ & $K S^{+/-}$ & Promotes & $\begin{array}{l}\text { Lipoatrophy, thin/translucent skin, } \\
\text { prematurely aged appearance }\end{array}$ & V665A & Johnston et al. 2015 \\
\hline Fibrosis of skin/fat & $K S^{-/-}$ & Inhibits & Lipodystrophy, hyperelastic skin & P584R, W566R & $\begin{array}{l}\text { Takenouchi et al. 2015; } \\
\text { Minatogawa et al. } 2017\end{array}$ \\
\hline Autoinflammation & $K S^{+/-}$ & Promotes & Not characterized & & \\
\hline Vascular defects & $K S^{+/-}, K S^{-/-}$ & Independent $\mathrm{t}^{\mathrm{b}}$ & Not characterized & & \\
\hline Not characterized & & & $\begin{array}{l}\text { Intellectual disability, white } \\
\text { matter lesions }\end{array}$ & P584R, W566R & $\begin{array}{l}\text { Takenouchi et al. 2015; } \\
\quad \text { Minatogawa et al. } 2017\end{array}$ \\
\hline Not characterized & & & Infantile myofibromatosis & P584R, W566R & $\begin{array}{l}\text { Takenouchi et al. 2015; } \\
\text { Minatogawa et al. } 2017\end{array}$ \\
\hline
\end{tabular}

${ }^{\mathrm{a}}$ The V665A mutation is linked to Penttinen syndrome. The P584R and W566R mutations are linked to Kosaki overgrowth syndrome.

${ }^{a}$ Vascular defects involving VSMC hyperplasia and aortic dilation are STAT1-independent. However, perivascular autoinflammation is STAT1-dependent (He et al. 2015).

dermal fibrosis and fat remodeling that is distinct from lipoatrophy in $\mathrm{KS}^{+/-}$mice. Similarly, Kosaki overgrowth syndrome is characterized by dermal and fat remodeling that appears phenotypically distinct from Penttinen syndrome.

There are some nonoverlapping phenotypes between Pdgfrb ${ }^{+/ D 849 V}$ mutant mice and humans with PDGFRBassociated syndromes, which highlights areas for future investigation (Table 1). Autoinflammation has not been characterized in humans. However, constitutive phosphorylation of STAT1 by the V664A and P583R mutant forms of PDGFR $\beta$ (Fig. 1A) suggests that autoinflammatory features may yet be revealed. Vascular defects that were seen in the original Sox2-Cre;Pdgfrb ${ }^{+/ D 849 V}$ mutants (Olson and Soriano 2011) and VSMC-selective Sm22a-Cre; Pdgfrb ${ }^{+/ D 849 V}$ mutants (He et al. 2015) have not been reported in humans. Interestingly, VSMC hyperplasia in $P d g f r b^{+/ D 849 V}$ mutants was not rescued by Stat1 deletion, suggesting that STAT1 modulates PDGFR $\beta$ growth-related signaling differently in fibroblasts and VSMCs. On the other hand, infantile myofibromas, intellectual disability, and white matter lesions have been reported in patients with Kosaki overgrowth syndrome (Takenouchi et al. 2015; Minatogawa et al. 2017), but, so far, we have not characterized such defects in $P d g f_{r} b^{+/ D 849 V}$ mutant mice. Some of these differences may be resolved by further characterization of mouse/human subjects.

Elevated PDGF signaling promotes fibroblast proliferation and collagen synthesis, which is important for wound healing but can cause fibrotic diseases in many organ systems. The significance of PDGF as a profibrotic signal was highlighted recently in a preclinical model of systemic sclerosis, where specific pharmacological inhibition of PDGFR $\alpha / \beta$ attenuated dermal and cardiac fibrosis (Makino et al. 2017). However, the respective importance of PDGFR $a$ versus PDGFR $\beta$ is not entirely clear. We reported previously that increased PDGFRa signaling via a
PDGFR ${ }^{\mathrm{D} 842 \mathrm{~V}}$ mutation caused multiorgan fibrosis, but PDGFR $\beta^{\mathrm{D} 849 \mathrm{~V}}$ caused autoinflammation without fibrosis (Olson and Soriano 2009, 2011; Iwayama and Olson 2013; Iwayama et al. 2015). A comparison in skeletal muscle also found greater fibrogenic potential from PDGFRa (Ieronimakis et al. 2016). A reason for this functional difference is revealed by our genetic studies: The profibrotic effects of PDGFR $\beta^{\mathrm{D} 849 \mathrm{~V}}$ are limited by STAT1 activity. This is not the case for PDGFR ${ }^{\mathrm{D} 842 \mathrm{~V}}$, which induces weak STAT1 phosphorylation compared with PDGFR $\beta^{\mathrm{D} 849 \mathrm{~V}}$ in transient transfection experiments (data not shown).

PDGFR $a$ is crucial for the development of the craniofacial bones and axial skeleton (Klinghoffer et al. 2002; Moenning et al. 2009; Olson and Soriano 2009; He and Soriano 2013; Fantauzzo and Soriano 2014). More recent work has shown that PDGFR $\beta$ has a role in neural crestdirected development of craniofacial bones, where it cooperates with PDGFRa (Fantauzzo and Soriano 2016). However, a role for either receptor in the postnatal skeleton has been less clear. Our results show that elevated PDGFR $\beta$ signaling causes skeletal defects that are reminiscent of human disease. These phenotypes may arise from defective behavior of bone stem/progenitor cells, but this requires further investigation. It is known that osteoclasts, a hematopoietic cell type involved in bone reabsorption, secrete PDGF-B to recruit PDGFR $\beta^{+}$osteoblast precursors to sites of bone formation (Kubota et al. 2002; SanchezFernandez et al. 2008). PDGF can increase bone strength in rodents either when administered systematically or by implantation of hematopoietic cells engineered to secrete PDGF-B (Mitlak et al. 1996; Chen et al. 2015). However, it is unclear which receptor mediates this effect because PDGF-B can activate both PDGFR $\alpha$ and PDGFR $\beta$. In cultured bone marrow stromal cells, PDGFR $\beta$ supports proliferation and migration while inhibiting osteogenic differentiation (Tokunaga et al. 2008). Elevated PDGFR $\beta$ 
signaling would thus be expected to enhance osteoprogenitor proliferation and migration. We now show that PDGFR $\beta$ indeed regulates postnatal bone growth. Paradoxically, PDGFR $\beta^{\mathrm{D} 849 \mathrm{~V}}$ either inhibits or enhances bone growth in the presence or absence of STAT1, respectively. However, one caveat for understanding PDGFR $\beta-$ STAT1 signaling in bones is that Stat $1^{-/-}$mice have mildly increased bone growth, as we confirmed in $S^{-/-}$calvaria (thickness) and growth plates (width). Increased osteoblast/chondroblast proliferation in $S^{-/-}$mice has been explained by changes in Runx 2 transcriptional activity and Fgfr3 signaling (Kim et al. 2003; Murakami et al. 2004; Xiao et al. 2004), but PDGFR $\beta$ was not examined. Therefore, as STAT1 likely touches multiple aspects of bone growth and remodeling, the Stat $1^{-/-}$background may amplify the effect of PDGFR $\beta^{\mathrm{D} 849 \mathrm{~V}}$ in bones through more than one mechanism.

\section{Materials and methods}

Mice

Mouse strains PDGFR $\beta^{\text {D849V }}$ (018435), Sox2-Cre (008454), Sm22a-Cre (017491), STAT1 ${ }^{\text {flox }}$ (012901), Ifnar1 ${ }^{\text {flox }}$ (028256), and Ifngr $1^{\text {flox }}(025394)$ are available at the Jackson Laboratory. The Institutional Animal Care and Use Committee of the Oklahoma Medical Research Foundation approved all procedures performed on mice. Mice were examined in a mixed C57BL/6;129Sv genetic background and were fed a standard mouse chow diet. Mutant $\mathrm{KS}^{+/-}$and $\mathrm{KS}^{-/-}$mice were compared with age and sexmatched $\mathrm{S}^{+-}$and $\mathrm{S}^{-/-}$controls with the appropriate Cre driver. Littermates were used whenever possible.

\section{PDGFR $\beta$ expression in NIH3T3 cells}

Vectors were created to express wild-type mouse PDGFR $\beta$ or mutant isoforms with single amino acid change P583R, V664A, or D849V (corresponding to human P584R, V665A, or D850V). First, PCR-amplified wild-type or mutant cDNAs were inserted in pENTR (a gateway cloning-compatible construct; gift from Eric Campeau). Each construct was then mixed with pLenti CMV BLAST DEST (Eric Campeau) with Clonase II (Thermofisher) to yield the expression vectors here. A pLenti eGFP plasmid was used as a control. Two micrograms of plasmid was transfected into NIH3T3 cells with Lipofectamine 3000 (Thermofisher) in cells growing in DMEM with $0.1 \%$ FBS and no antibiotics. Cell lysates were collected $24 \mathrm{~h}$ later.

RNA isolation and quantitative RT-PCR ( $q R T-P C R$ )

Total RNA was isolated from mouse ingWAT tissues using RNeasy kit (Qiagen) or from cultured DFs using Trizol (ThermoFisher). cDNA reverse transcription was performed using random primers and SuperScript III RT (Invitrogen). qPCR was performed on a Bio-Rad iCycler with iQ SYBR Green master mix. Results were normalized to Gapdh. Primer sequences are listed in the Supplemental Material.

\section{Flow cytometry}

Fat pads (ingWAT) were minced and digested with $300 \mu \mathrm{g} / \mathrm{mL}$ collagenase type I(Life Technologies) in Hank's balanced salt sol-

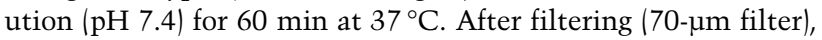
cells were resuspended in PBS with $1 \mathrm{mM}$ EDTA and $2 \%$ FBS and incubated with Fc-blocking antibody (eBioscience) for 15 min on ice before staining with FITC-CD45.2 antibody $11: 100$; Biolegend). Cells were also stained with propidium iodide to identify live/dead cells. After washing, immunofluorescence was detected by an LSR II (BD Biosciences). Data were analyzed by post-collection compensation using FlowJo software (Tree Star, Inc.).

\section{Primary DFs and Western blotting}

After removing hair with cream (Nair), mouse DFs were isolated from 2- to 3-wk-old mice by explanting $1-\mathrm{mm}^{2}$ pieces of skin, dermis side down, with DMEM plus $10 \%$ FBS, $25 \mathrm{U} / \mathrm{mL}$ penicillin/ streptomycin, and $2 \mathrm{mM}$ L-glutamine. After $2 \mathrm{wk}$, skin pieces were removed, and DFs were passaged. All assays were performed at passages $2-5$. For Western blotting, cells were starved in medium containing $0.1 \%$ FBS for $24 \mathrm{~h}$ and then treated with $10 \mathrm{ng} / \mathrm{mL}$ PDGF-BB (R\&D Systems) for $10 \mathrm{~min}$ or according to a time course. Cells were lysed in RIPA buffer $(50 \mathrm{mM}$ Tris at $\mathrm{pH} 7.4,1 \%$ NP-40, $0.25 \%$ sodium deoxycholate, $150 \mathrm{mM} \mathrm{NaCl}, 0.1 \%$ sodium dodecyl sulfate) with $1 \mathrm{mM} \mathrm{NaF}, \mathrm{Na}_{3} \mathrm{VO}_{4}, \mathrm{PMSF}$, and $1 \times$ protease inhibitor cocktail (Complete, Roche), and protein concentration was determined by Pierce BCA assay (ThermoFisher). Five micrograms or $10 \mu \mathrm{g}$ of protein was then separated by SDS-PAGE and transferred to nitrocellulose membranes, blocked with 5\% BSA, and then subjected to Western blotting with primary antibodies listed in the Supplemental Material. Membranes were then probed with horseradish peroxidase-conjugated secondary antibodies at 1:5000 (Jackson ImmunoResearch) in 5\% milk. Blots were developed with Pierce ECL Western blotting substrate (ThermoFisher) and autoradiography film (Santa Cruz Biotechnology).

Tissue and histology

Tissue was immersion-fixed overnight in $4 \%$ paraformaldehyde (PFA; Electron Microscopy Sciences) or Bouin's fixative (Sigma). Hair was removed with cream (Nair). Bones were decalcified in $10 \%$ EDTA solution for 1 wk. For histochemical staining, Bouin's-fixed tissues were embedded in paraffin and sectioned at $5 \mu \mathrm{m}$ before staining with Masson's Trichrome (Electron Microscopy Sciences) or hematoxylin and eosin (Vector Laboratories). For immunohistochemistry, PFA-fixed samples were cryosectioned at $8 \mu \mathrm{m}$ and stained with primary antibodies listed in the Supplemental Material. This was followed by the appropriate donkey secondary antibodies (Jackson ImmunoResearch) and DAPI (Sigma) as a nuclear stain. Immunofluorescence microscopy was performed with a Nikon Eclipse 80i microscope connected to a digital camera.

\section{Whole-mount analysis of bones}

Skin was removed, and pups were fixed in 100\% EtOH for $3 \mathrm{~d}$ followed by Alcian blue stain (15 mg of Alcian blue, $80 \mathrm{~mL}$ of $95 \%$ $\mathrm{EtOH}, 20 \mathrm{~mL}$ of glacial acetic acid) for $12 \mathrm{~h}$. Next, the skeletons were rinsed in $100 \%$ EtOH overnight, cleared in $1 \% \mathrm{KOH}$ for 6 $\mathrm{h}$, and then counterstained in $5 \mathrm{mg}$ of Alizarin red in $100 \mathrm{~mL}$ of $1 \% \mathrm{KOH}$ overnight. Skeletons were then cleared in $1 \% \mathrm{KOH}$, washed in a graded series of $1 \% \mathrm{KOH}$ and glycerol, and finally stored in $100 \%$ glycerol. Adult skeletons were treated similarly except for overnight trypsin treatment (1\% trypsin in 7:3 distilled $\mathrm{H}_{2} \mathrm{O}$ :saturated sodium borate solution) before preclearing in $2 \%$ $\mathrm{KOH}$, and all subsequent steps were performed in $2 \% \mathrm{KOH}$. 


\section{Statistical analysis}

Data are expressed as mean \pm standard deviation unless indicated otherwise. All calculations were performed using GraphPad Prism 6.0. The differences between two groups (usually $\mathrm{S}^{+/-}$vs. $\mathrm{KS}^{+/-}$, or $\mathrm{S}^{-/-}$vs. $\mathrm{KS}^{-1-}$ ) were assessed by unpaired Student's $t$ test unless indicated otherwise. A value of $P<0.05$ was considered statistically significant. The significant differences in mouse survival were determined by a log-rank test.

\section{Acknowledgments}

We thank Cameron Steele, Tony Tang, Linda Thompson, James Tomasek, Mary Beth Humphrey, and Yanick Crow for their assistance and helpful discussion. We also thank the Flow Cytometry Core Facility and Imaging Core Facility (associated with P20GM103636) and the Mouse Phenotyping Core Facility (associated with P30GM114731) of the Oklahoma Medical Research Foundation Centers of Biomedical Research Excellence. These studies were funded by National Institutes of Health grants (P20GM103636 and R01AR070235), a grant from the Oklahoma Center for Adult Stem Cell Research, and the Pew Charitable Trusts. C.S. and S.C.M. were supported by predoctoral fellowships from the American Heart Association.

\section{References}

Andrae J, Gallini R, Betsholtz C. 2008. Role of platelet-derived growth factors in physiology and medicine. Genes Dev 22: 1276-1312.

Arts FA, Chand D, Pecquet C, Velghe AI, Constantinescu S, Hallberg B, Demoulin JB. 2016. PDGFRB mutants found in patients with familial infantile myofibromatosis or overgrowth syndrome are oncogenic and sensitive to imatinib. Oncogene 35: 3239-3248.

Bonner JC. 2004. Regulation of PDGF and its receptors in fibrotic diseases. Cytokine Growth Factor Rev 15: 255-273.

Chen W, Baylink DJ, Brier-Jones J, Neises A, Kiroyan JB, Rundle $\mathrm{CH}$, Lau KH, Zhang XB. 2015. PDGFB-based stem cell gene therapy increases bone strength in the mouse. Proc Natl Acad Sci 112: E3893-E3900.

Cheung YH, Gayden T, Campeau PM, LeDuc CA, Russo D, Nguyen VH, Guo J, Qi M, Guan Y, Albrecht S, et al. 2013. A recurrent PDGFRB mutation causes familial infantile myofibromatosis. Am J Hum Genet 92: 996-1000.

Crow YJ, Manel N. 2015. Aicardi-Goutieres syndrome and the type I interferonopathies. Nat Rev Immunol 15: 429-440.

Crow YJ, Hayward BE, Parmar R, Robins P, Leitch A, Ali M, Black DN, van Bokhoven H, Brunner HG, Hamel BC, et al. 2006. Mutations in the gene encoding the $3^{\prime}-5^{\prime}$ DNA exonuclease TREX1 cause Aicardi-Goutieres syndrome at the AGS1 locus. Nat Genet 38: 917-920.

Delgoffe GM, Vignali DA. 2013. STAT heterodimers in immunity: a mixed message or a unique signal? JAKSTAT 2: e23060.

Driskell RR, Jahoda CA, Chuong CM, Watt FM, Horsley V. 2014. Defining dermal adipose tissue. Exp Dermatol 23: 629-631.

Durbin JE, Hackenmiller R, Simon MC, Levy DE. 1996. Targeted disruption of the mouse Stat 1 gene results in compromised innate immunity to viral disease. Cell 84: 443-450.

Fantauzzo KA, Soriano P. 2014. PI3K-mediated PDGFRa signaling regulates survival and proliferation in skeletal development through p53-dependent intracellular pathways. Genes Dev 28: 1005-1017.
Fantauzzo KA, Soriano P. 2016. PDGFR $\beta$ regulates craniofacial development through homodimers and functional heterodimers with PDGFRa. Genes Dev 30: 2443-2458.

Gough DJ, Messina NL, Clarke CJ, Johnstone RW, Levy DE. 2012. Constitutive type I interferon modulates homeostatic balance through tonic signaling. Immunity 36: 166-174.

Gresser I, Morel-Maroger L, Riviere Y, Guillon JC, Tovey MG, Woodrow D, Sloper JC, Moss J. 1980. Interferon-induced disease in mice and rats. Ann NY Acad Sci 350: 12-20.

He F, Soriano P. 2013. A critical role for PDGFRa signaling in medial nasal process development. PLoS Genet 9: e1003851.

He C, Medley SC, Hu T, Hinsdale ME, Lupu F, Virmani R, Olson LE. 2015. PDGFR $\beta$ signalling regulates local inflammation and synergizes with hypercholesterolaemia to promote atherosclerosis. Nat Commun 6: 7770.

Heldin CH, Westermark B. 1999. Mechanism of action and in vivo role of platelet-derived growth factor. Physiol Rev 79: 1283-1316.

Ieronimakis N, Hays A, Prasad A, Janebodin K, Duffield JS, Reyes M. 2016. PDGFRa signalling promotes fibrogenic responses in collagen-producing cells in Duchenne muscular dystrophy. $I$ Pathol 240: 410-424.

Iwayama T, Olson LE. 2013. Involvement of PDGF in fibrosis and scleroderma: recent insights from animal models and potential therapeutic opportunities. Curr Rheumatol Rep 15: 304.

Iwayama T, Steele C, Yao L, Dozmorov MG, Karamichos D, Wren JD, Olson LE. 2015. PDGFRa signaling drives adipose tissue fibrosis by targeting progenitor cell plasticity. Genes Dev 29: 1106-1119.

Johnston JJ, Sanchez-Contreras MY, Keppler-Noreuil KM, Sapp J, Crenshaw M, Finch NA, Cormier-Daire V, Rademakers R, Sybert VP, Biesecker LG. 2015. A point mutation in PDGFRB causes autosomal-dominant Penttinen syndrome. Am I Hum Genet 97: 465-474.

Karlsson C, Thornemo M, Henriksson HB, Lindahl A. 2009. Identification of a stem cell niche in the zone of Ranvier within the knee joint. I Anat 215: 355-363.

Kazi JU, Kabir NN, Flores-Morales A, Ronnstrand L. 2014. SOCS proteins in regulation of receptor tyrosine kinase signaling. Cell Mol Life Sci 71: 3297-3310.

Keller A, Westenberger A, Sobrido MJ, Garcia-Murias M, Domingo A, Sears RL, Lemos RR, Ordonez-Ugalde A, Nicolas G, da Cunha JE, et al. 2013. Mutations in the gene encoding PDGF-B cause brain calcifications in humans and mice. Nat Genet 45: 1077-1082.

Kim S, Koga T, Isobe M, Kern BE, Yokochi T, Chin YE, Karsenty G, Taniguchi T, Takayanagi H. 2003. Statl functions as a cytoplasmic attenuator of Runx2 in the transcriptional program of osteoblast differentiation. Genes Dev 17: 1979-1991.

Klinghoffer RA, Hamilton TG, Hoch R, Soriano P. 2002. An allelic series at the PDGFaR locus indicates unequal contributions of distinct signaling pathways during development. Dev Cell 2: 103-113.

Kubota K, Sakikawa C, Katsumata M, Nakamura T, Wakabayashi K. 2002. Platelet-derived growth factor BB secreted from osteoclasts acts as an osteoblastogenesis inhibitory factor. J Bone Miner Res 17: 257-265.

Levy DE, Darnell JE Jr. 2002. Stats: transcriptional control and biological impact. Nat Rev Mol Cell Biol 3: 651-662.

Linossi EM, Babon JJ, Hilton DJ, Nicholson SE. 2013. Suppression of cytokine signaling: the SOCS perspective. Cytokine Growth Factor Rev 24: 241-248.

Makino K, Makino T, Stawski L, Mantero JC, Lafyatis R, Simms R, Trojanowska M. 2017. Blockade of PDGF receptors by crenolanib has therapeutic effect in patient fibroblasts and in 
preclinical models of systemic sclerosis. I Invest Dermatol 137: 1671-1681.

Martignetti JA, Tian L, Li D, Ramirez MC, Camacho-Vanegas O, Camacho SC, Guo Y, Zand DJ, Bernstein AM, Masur SK, et al. 2013. Mutations in PDGFRB cause autosomal-dominant infantile myofibromatosis. Am J Hum Genet 92: 1001-1007.

Meraz MA, White JM, Sheehan KC, Bach EA, Rodig SJ, Dighe AS, Kaplan DH, Riley JK, Greenlund AC, Campbell D, et al. 1996. Targeted disruption of the Statl gene in mice reveals unexpected physiologic specificity in the JAK-STAT signaling pathway. Cell 84: 431-442.

Minatogawa M, Takenouchi T, Tsuyusaki Y, Iwasaki F, Uehara T, Kurosawa K, Kosaki K, Curry CJ. 2017. Expansion of the phenotype of Kosaki overgrowth syndrome. Am I Med Genet A 173: 2422-2427.

Mitlak BH, Finkelman RD, Hill EL, Li J, Martin B, Smith T, D'Andrea M, Antoniades HN, Lynch SE. 1996. The effect of systemically administered PDGF-BB on the rodent skeleton. I Bone Miner Res 11: 238-247.

Moenning A, Jager R, Egert A, Kress W, Wardelmann E, Schorle H. 2009. Sustained platelet-derived growth factor receptor $\alpha$ signaling in osteoblasts results in craniosynostosis by overactivating the phospholipase C- $\gamma$ pathway. Mol Cell Biol 29: 881-891.

Murakami S, Balmes G, McKinney S, Zhang Z, Givol D, de Crombrugghe B. 2004. Constitutive activation of MEK1 in chondrocytes causes Stat1-independent achondroplasia-like dwarfism and rescues the Fgfr3-deficient mouse phenotype. Genes Dev 18: 290-305.

Nicolas G, Pottier C, Maltete D, Coutant S, Rovelet-Lecrux A, Legallic S, Rousseau S, Vaschalde Y, Guyant-Marechal L, Augustin J, et al. 2013. Mutation of the PDGFRB gene as a cause of idiopathic basal ganglia calcification. Neurology 80: 181-187.

Olson LE, Soriano P. 2009. Increased PDGFR $\alpha$ activation disrupts connective tissue development and drives systemic fibrosis. Dev Cell 16: 303-313.

Olson LE, Soriano P. 2011. PDGFR $\beta$ signaling regulates mural cell plasticity and inhibits fat development. Dev Cell 20: 815-826.

Pond D, Arts FA, Mendelsohn NJ, Demoulin JB, Scharer G, Messinger Y. 2017. A patient with germ-line gain-of-function PDGFRB p.N666H mutation and marked clinical response to imatinib. Genet Med doi: 10.1038/gim.2017.104.
Sahni M, Raz R, Coffin JD, Levy D, Basilico C. 2001. STAT1 mediates the increased apoptosis and reduced chondrocyte proliferation in mice overexpressing FGF2. Development 128: 2119-2129.

Sanchez-Fernandez MA, Gallois A, Riedl T, Jurdic P, Hoflack B. 2008. Osteoclasts control osteoblast chemotaxis via PDGFBB/PDGF receptor $\beta$ signaling. PLoS One 3: e3537.

Shapiro F, Holtrop ME, Glimcher MJ. 1977. Organization and cellular biology of the perichondrial ossification groove of ranvier: a morphological study in rabbits. I Bone Joint Surg Am 59: 703-723.

Silvennoinen O, Schindler C, Schlessinger J, Levy DE. 1993. Rasindependent growth factor signaling by transcription factor tyrosine phosphorylation. Science 261: 1736-1739.

Stetson DB, Ko JS, Heidmann T, Medzhitov R. 2008. Trex1 prevents cell-intrinsic initiation of autoimmunity. Cell 134: 587-598.

Sun C, Berry WL, Olson LE. 2017. PDGFRa controls the balance of stromal and adipogenic cells during adipose tissue organogenesis. Development 144: 83-94.

Takenouchi T, Yamaguchi Y, Tanikawa A, Kosaki R, Okano H, Kosaki K. 2015. Novel overgrowth syndrome phenotype due to recurrent de novo PDGFRB mutation. I Pediatr 166: 483-486.

Tallquist M, Kazlauskas A. 2004. PDGF signaling in cells and mice. Cytokine Growth Factor Rev 15: 205-213.

Tallquist MD, French WJ, Soriano P. 2003. Additive effects of PDGF receptor $\beta$ signaling pathways in vascular smooth muscle cell development. PLOS Biol 1: E52.

Tokunaga A, Oya T, Ishii Y, Motomura H, Nakamura C, Ishizawa S, Fujimori T, Nabeshima Y, Umezawa A, Kanamori M, et al. 2008. PDGF receptor $\beta$ is a potent regulator of mesenchymal stromal cell function. J Bone Miner Res 23: 1519-1528.

Xiao L, Naganawa T, Obugunde E, Gronowicz G, Ornitz DM, Coffin JD, Hurley MM. 2004. Stat1 controls postnatal bone formation by regulating fibroblast growth factor signaling in osteoblasts. J Biol Chem 279: 27743-27752.

Yang W, Wang J, Moore DC, Liang H, Dooner M, Wu Q, Terek R, Chen Q, Ehrlich MG, Quesenberry PJ, et al. 2013. Ptpn11 deletion in a novel progenitor causes metachondromatosis by inducing hedgehog signalling. Nature 499: 491-495.

Zhao H, Feng J, Ho TV, Grimes W, Urata M, Chai Y. 2015. The suture provides a niche for mesenchymal stem cells of craniofacial bones. Nat Cell Biol 17: 386-396. 


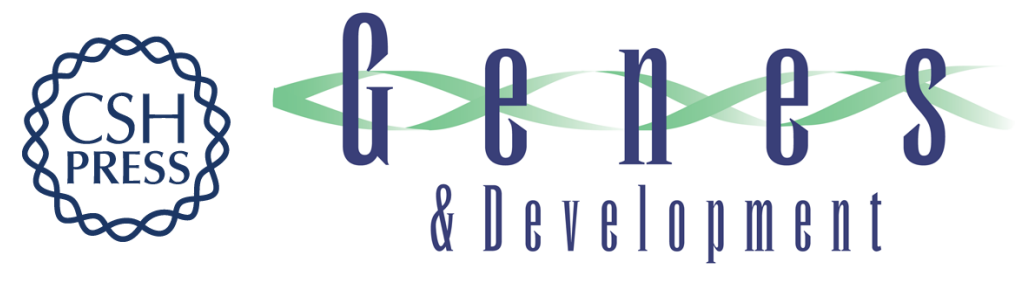

\title{
STAT1 modulates tissue wasting or overgrowth downstream from PDGFR $\beta$
}

\author{
Chaoyong He, Shayna C. Medley, Jang Kim, et al.
}

Genes Dev. 2017, 31: originally published online September 18, 2017

Access the most recent version at doi:10.1101/gad.300384.117

\section{Supplemental http://genesdev.cshlp.org/content/suppl/2017/09/18/gad.300384.117.DC1 Material \\ References This article cites 53 articles, 13 of which can be accessed free at: http://genesdev.cshlp.org/content/31/16/1666.full.html\#ref-list-1 \\ Creative This article is distributed exclusively by Cold Spring Harbor Laboratory Press for the first Commons six months after the full-issue publication date (see \\ License http://genesdev.cshlp.org/site/misc/terms.xhtml). After six months, it is available under a Creative Commons License (Attribution-NonCommercial 4.0 International), as described at http://creativecommons.org/licenses/by-nc/4.0/. \\ Email Alerting Receive free email alerts when new articles cite this article - sign up in the box at the top Service right corner of the article or click here.}

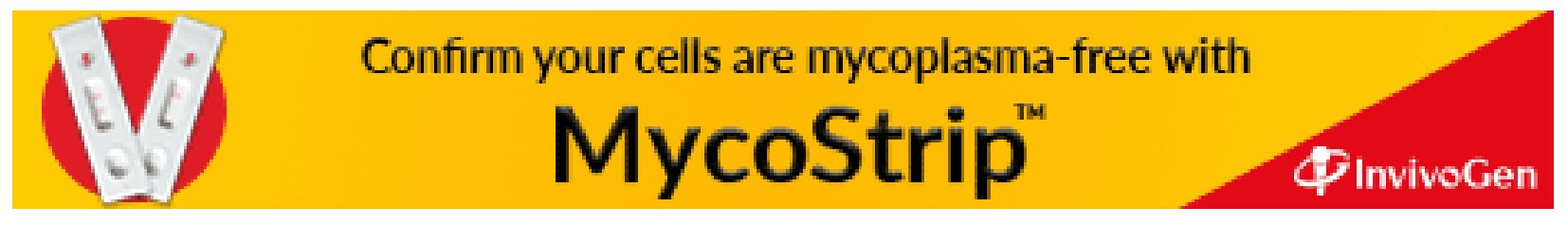

